\title{
Genetic Environments of the Eunjeok Au-Ag Deposit in the Yeongam District: Implications for Cretaceous Epithermal Au-Ag Mineralization in South Korea
}

\author{
Chul-Ho Heo ${ }^{1}$, Seong-Yong Kim ${ }^{2}\left[\right.$ and Il-Hwan $\mathrm{Oh}^{1, *}$ (]) \\ 1 Mineral Resources Development Research Center, Korea Institute of Geoscience and Mineral Resources, \\ Daejeon 34132, Korea; chheo@kigam.re.kr \\ 2 Geo-Technology Policy Research Center, Korea Institute of Geoscience and Mineral Resources, \\ Daejeon 34132, Korea; ksy@kigam.re.kr \\ * Correspondence: ilhwan@kigam.re.kr; Tel.: +82-42-868-5005
}

Citation: Heo, C.-H.; Kim, S.-Y.; Oh, I.-H. Genetic Environments of the Eunjeok Au-Ag Deposit in the Yeongam District: Implications for Cretaceous Epithermal Au-Ag Mineralization in South Korea. Minerals 2021, 11, 1088. https:// doi.org/10.3390/min11101088

Academic Editor: Martin Reich

Received: 22 August 2021

Accepted: 30 September 2021

Published: 3 October 2021

Publisher's Note: MDPI stays neutral with regard to jurisdictional claims in published maps and institutional affiliations.

Copyright: (c) 2021 by the authors. Licensee MDPI, Basel, Switzerland. This article is an open access article distributed under the terms and conditions of the Creative Commons Attribution (CC BY) license (https:/ / creativecommons.org/licenses/by/ $4.0 /)$.

\begin{abstract}
Eunjeok Au-Ag deposits are situated in the Yeongam district, Cheollanamdo-province, South Korea. They are genetically related to the Bulgugsa magmatic event (ca. 110-60 Ma), caused by the transition in the subduction direction and style of the Izanagi Plate. Three gold- and silver-bearing hydrothermal veins filled the fractures of the Cretaceous rhyolitic tuff. The major ore minerals were arsenopyrite (31.47-32.20 at.\% As), pyrite, chalcopyrite, sphalerite (8.58-10.71 FeS mole\%) and galena with minor amounts of electrum (62.77-78.15 at.\% Au), native silver, and argentite. Sericitization was dominant in the alteration zone. The various textures of quartz veins (i.e., breccia, crustiform, comb, and vuggy) may indicate the formation of an epithermal environment. The auriferous fluids with the $\mathrm{H}_{2} \mathrm{O}-\mathrm{NaCl}$ system have homogenization temperatures and salinities of $204^{\circ} \mathrm{C}$ to $314{ }^{\circ} \mathrm{C}$, less than $10 \mathrm{wt} . \%$ equiv. $\mathrm{NaCl}$, and experienced mixing (dilution and cooling) events during mineralization. Considering the characteristics of the geologic setting, major fault system, and host rock, the Eunjeok $\mathrm{Au}-\mathrm{Ag}$ deposit within the Yeongam district tends to share the general geologic characteristics of Haenam-Jindo epithermal mineralization episodes. However, the age of gold-silver mineralization $(86.0 \mathrm{Ma})$ is older than that of Haenam-Jindo epithermal mineralization episodes ( $<70.3 \mathrm{Ma})$, implying some differences exist in the genetic sequence of extensional characteristics caused by transcurrent Gwangju-Yeongdong faults.
\end{abstract}

Keywords: Eunjeok deposit; epithermal gold-silver; Late Cretaceous magmatism

\section{Introduction}

Cretaceous epithermal gold-silver deposits in South Korea are tectonically related to pull-apart basins and volcano-tectonic depressions [1-3]. Two representative epithermal gold-silver mineralized areas are the Mugeuk and the Haenam-Jindo districts [1-10] (Figure 1). The major veins in these districts occur in subvolcanic to volcanic rocks of approximately similar ages [1,2]. Cretaceous epithermal gold-silver mineralization in South Korea may imply that the tectonic setting developed into suitable conditions for ore deposit genesis in shallow crustal environments [1,2].

The Eunjeok Au-Ag deposit is located in Taebaek-ri, Seoho-myeon, Yeongam-gun, Cheollanamdo-province, in terms of administrative district, and corresponds to $34^{\circ} 47^{\prime} 47.7^{\prime \prime} \mathrm{N}$ and $126^{\circ} 32^{\prime} 43^{\prime \prime} \mathrm{E}$ in terms of geographic coordinates. As for the current status of exploration in this deposit area, the Korea Resources Corporation (KORES) conducted test drilling in 1984 (four holes, $450 \mathrm{~m}$ ) and 1985 (three holes, $300 \mathrm{~m}$ ). Three shafts (lower main shaft, upper main shaft, and upper shaft) were excavated for more than $1200 \mathrm{~m}$ within the deposit. They are currently not accessible except for the upper pit, and the entrance to the lower conduit was flooded, and the main conduit collapsed making it impossible to enter the adit [11]. 


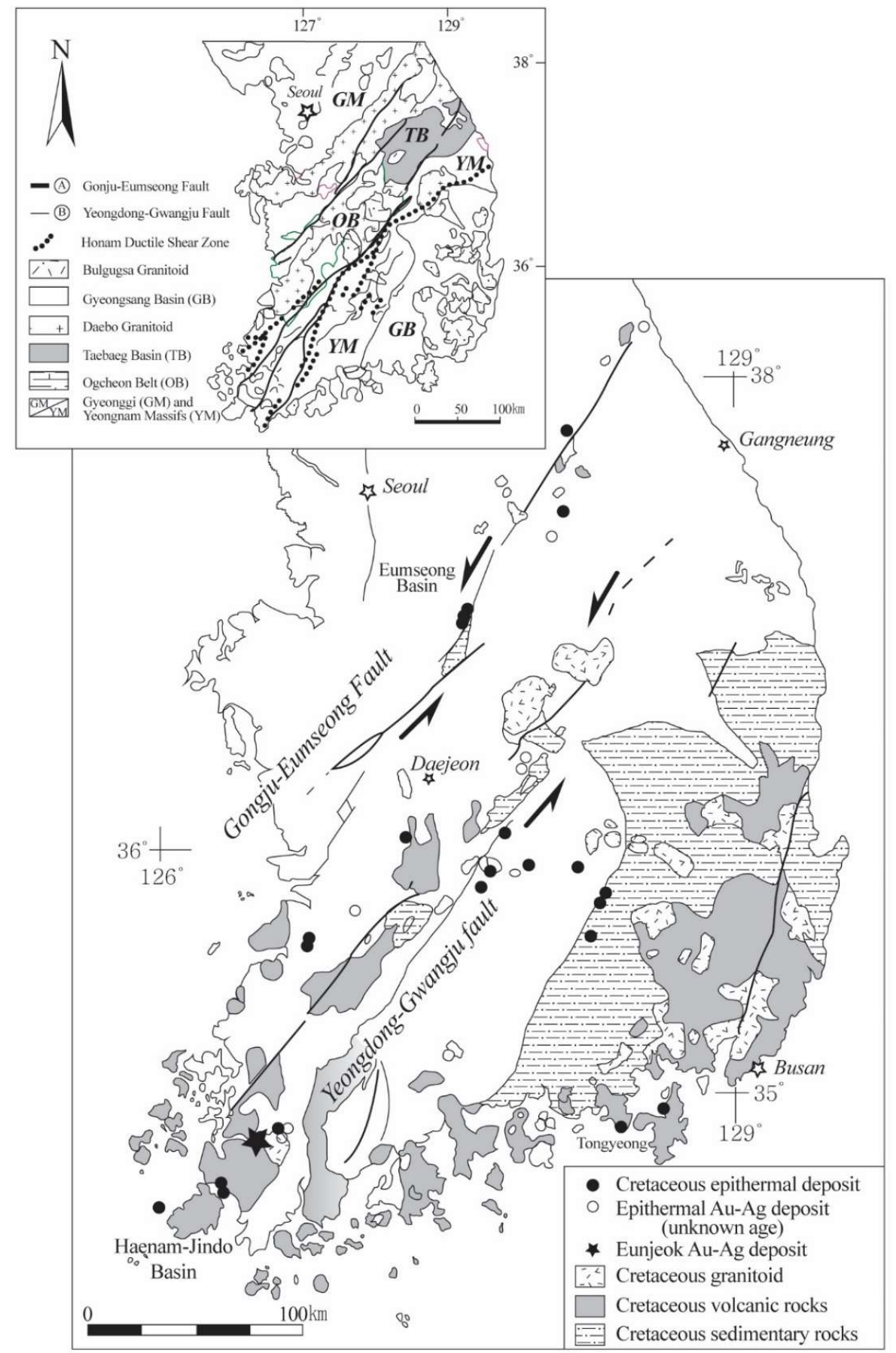

Figure 1. Simplified geological map of South Korea showing the distribution of Cretaceous basins and major epithermal gold-silver deposits. This figure was entirely modified from [2].

Several studies have been conducted by previous researchers on the geology and physicochemical conditions of $\mathrm{Au}-\mathrm{Ag}$ mineralization in the deposits. The researchers in [12] documented that the $\mathrm{N} 10-15^{\circ} \mathrm{W}$ trending veins emplaced along fissures and breccia zones in rhyolitic tuffs occur at Eunjeok and Sangeun $\mathrm{Au}-\mathrm{Ag}$ deposits within the Yeongam district in South Korea. Three stages of mineral deposition were identified in the deposits. The major constituent minerals are pyrite, arsenopyrite, sphalerite, chalcopyrite, galena, pyrrhotite, electrum, and native silver. The Eunjeok and Sangeun deposits have gold content of electrum from 10.10 to 33.24 at. \% and 16.78 to 20.72 at. \%, respectively. They have homogenization temperatures of fluid inclusions in quartz from 170 to $328^{\circ} \mathrm{C}$ and 190 to $323{ }^{\circ} \mathrm{C}$, respectively. The $\delta^{34} \mathrm{~S}$ values, with an average of $4.8 \%$, may imply that 
sulfide sulfur is derived from magmatic origin. These results suggest that the Eunjeok and Sangeun deposits are classified as epithermal-to-mesothermal type. Furthermore, [11] reported that gold and silver deposits within the Eunjeok deposit have three gold- and silver-bearing hydrothermal veins that fill the fracture of the Cretaceous rhyolitic tuff. The major ore minerals are arsenopyrite, pyrite, chalcopyrite, sphalerite, galena, electrum, and argentite. Sericitization was dominant in the alteration zone. Various vein textures of quartz veins (i.e., breccia, crustiform, comb, and vuggy) may indicate the formation of an epithermal environment.

In this study, we aim to focus on the physicochemical conditions of the auriferous hydrothermal system favorable for the genesis of the Eunjeok deposit, using geological, mineralogical, geochemical, fluid inclusion, and stable isotope systematics.

\section{Tectonic Framework}

From north to south, the tectonostratigraphic units in South Korea are divided into the Gyeonggi Massif (GM), Ogcheon (OB)-Taebaeg (TB) Belt, Yeongnam Massif (YM), and Gyeongsang Basin (GB; Figure 1). High-grade gneiss and schist of the Late Archean to Early Proterozoic ages occur in Gyeonggi and Yeongnam Massifs $[13,14]$. The Taebaeg and Ogcheon basins are distributed in the Ogcheon-Taebaeg Belt based on lithology and metamorphic grade (Figure 1). Non-fossil-bearing, metasedimentary, and volcanic rocks with low- to medium-grade with their ages not well constrained occur in the Ogcheon Basin [15]. In contrast, fossiliferous, non- or weakly metamorphosed sedimentary rocks of the Paleozoic to Early Mesozoic age occur in the Taebaeg Basin (Figure 1). Siliciclastic sedimentary and calc-alkaline volcanic rocks occur in the Cretaceous Gyeongsang Basin. The Izanagi Plate started to subduct northward beneath the Eurasian Plate in the Late Jurassic-Early Cretaceous, creating the NE-SW-trending Gongju-Eumseong and Yeongdong-Gwangju fault systems [16] (Figure 1). The strike-slip basins were developed by the left-lateral intorsion of these fault systems (Figure 1). In addition, abrupt loading caused by volcanoes locally affected the regional stress field [16]. Thus, the succeeding extension started to form local volcano-tectonic depressions such as the Haenam-Jindo Basin. Therefore, we believe that the Yeongam district, including the Eunjeok $\mathrm{Au}-\mathrm{Ag}$ deposit, is tectonically associated with the caldera structure related to the Yeongdong-Gwangju fault system (Figure 1).

\section{Geology}

Economic $\mathrm{Au}-\mathrm{Ag}$ mineralization from the Eunjeok deposit area was found to be associated with the Mogpo cauldron [17]. The Mogpo cauldron, $22 \mathrm{~km} \times 18 \mathrm{~km}$ in diameter, consists primarily of acidic volcanics, comprising approximately two-thirds of the cauldron volume and ring dike of granite, quartz porphyry, and felsite. Near the cauldron margin, high-angle gravity faults dip inward to the central portion of the cauldron (Figure 2). The acidic volcanics unconformably overlie the Precambrian gneiss complex and Jurassic granite and are intruded by Cretaceous granite and quartz porphyry. At the eastern aspect of the Mogpo cauldron, felsite, which extends over $13 \mathrm{~km}$ long and is less than $300 \mathrm{~m}$ in thickness, intrudes as ring dikes along the contact between volcanics and Cretaceous granite. Acidic volcanics primarily distributed in the Eunjeok $\mathrm{Au}-\mathrm{Ag}$ deposit area consist of dominant Jindo rhyolite and Hwangsan tuff. The Jindo rhyolite, which occupies the central portion of the cauldron, mainly comprises tuffaceous rocks such as rhyolitic welded tuff. This rock is interlayered by lapilli tuff, and rhyolitic lava flows in the Haenam area (Figure 3). The Hwangsan tuff consists, primarily, of air-fall tuff intercalated with pyroclastic rocks and trachytic tuff and often contains volcanic bombs. Coarse-grained pinkish biotite granite contacted along a high-angle fault contacted with the Jindo rhyolite, less than $2 \mathrm{~km}$ in width, extends over $20 \mathrm{~km}$ in the NW direction. 


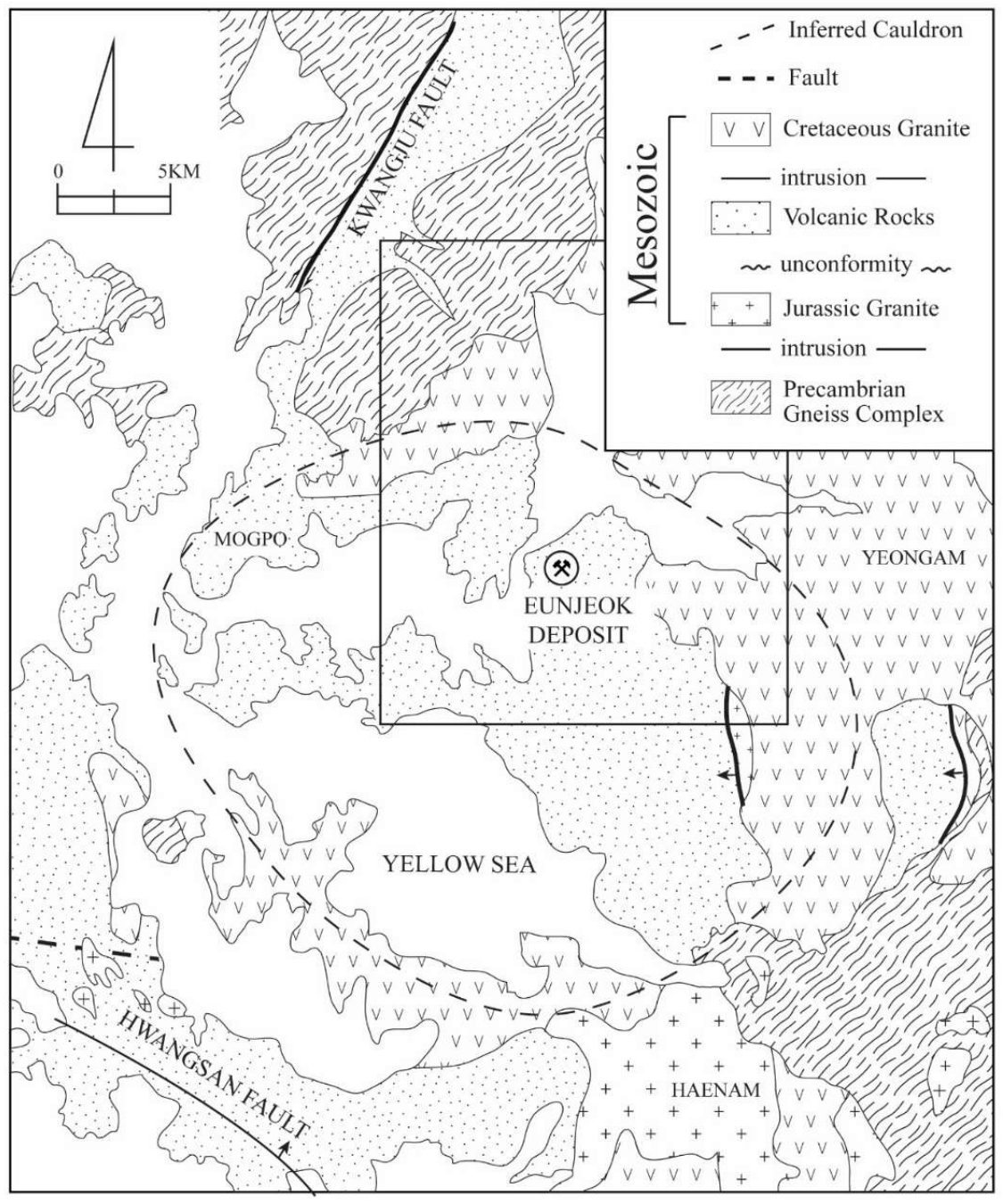

Figure 2. Regional geologic map including the Eunjeok deposit district modified from [11]. 


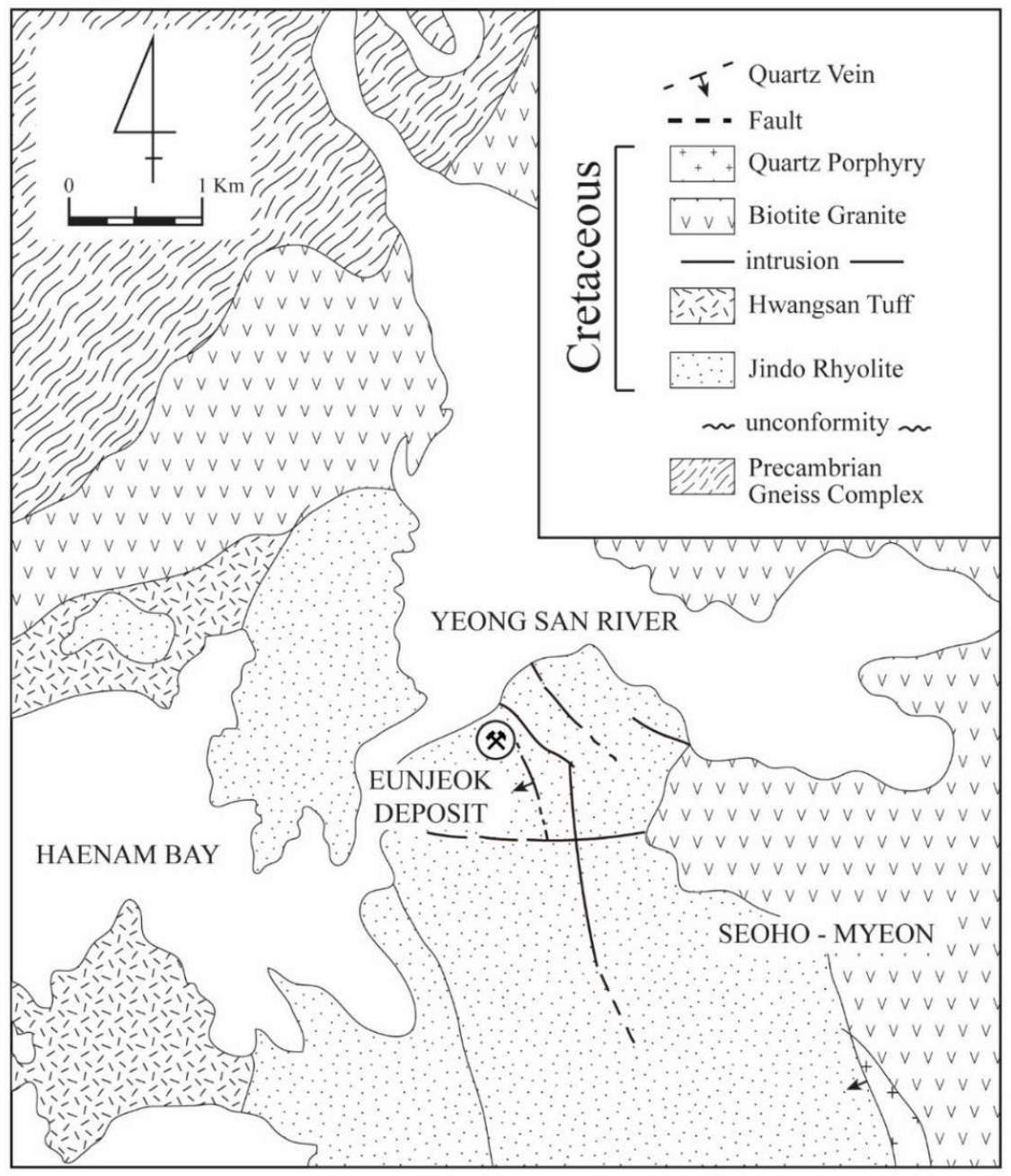

Figure 3. Local geological map of the Eunjeok gold-silver deposit area.

\section{Ore veins and Hydrothermal Alterations}

Within the deposit area, an extensive system of mainly NS- and NW-trending highangle gravity faults exists that were formed in the northeastern marginal parts of the Mogpo cauldron. Three Au-Ag-bearing hydrothermal quartz veins were created by narrow open space filling along the $\mathrm{N} 20-50^{\circ} \mathrm{W}$ trending fault planes in the Late Cretaceous volcanics. The productive veins can be traced for approximately $1 \mathrm{~km}$ along the strike and vary from 0.1 to $0.3 \mathrm{~m}$ in thickness. Repeated pinching and swelling of the veins along the strike and dip directions are common. The ore mineralization of quartz veins is simple metallic with local concentrations of sulfide minerals associated with economic quantities of silver and gold. The ore minerals occur as polycrystalline aggregates, disseminate, and often cocade ores around wall-rock breccias throughout the veins. Arsenopyrite and pyrite are disseminated as fine-grained crystals in altered wall-rock and tend to concentrate on the edges of the veins. Native silver occurs mostly in the central portions of veins and vugs. Rarely, ore veins display sulfide banding in mineral paragenesis from margins to centers: pyrite-arsenopyrite, sphalerite-galena-chalcopyrite, and native silver.

To carry out the preliminary feasibility study for deposit according to the commodity, common commodity ( $\mathrm{Pb}, \mathrm{Zn}, \mathrm{Cu}, \mathrm{Fe}, \mathrm{Mo}, \mathrm{W}, \mathrm{Au}$, and $\mathrm{U})$, and industrial commodity (In, Re, $\mathrm{Ga}, \mathrm{Ge}, \mathrm{Se}, \mathrm{Te}, \mathrm{Y}, \mathrm{Eu}$, and $\mathrm{Sm}$ ) for six ore specimens were analyzed (Table 1; Figure 4A-D). This analysis was conducted using an inductively coupled plasma emission spectrometer (ICP-AES) from the Korea Basic Science Institute. Results showed an unusually high gold contentment of $57.2 \mathrm{~g} / \mathrm{t}$ on average. Moreover, the silver content did not significantly exceed that of gold but averaged $197.7 \mathrm{~g} / \mathrm{t}$ (Table 1). 
Table 1. Analytical result of representative samples from the Eunjeok $\mathrm{Au}-\mathrm{Ag}$ deposit modified from [11].

\begin{tabular}{|c|c|c|c|c|c|c|c|c|c|c|c|c|c|c|c|c|c|c|c|}
\hline $\begin{array}{c}\text { Elements } \\
\text { Sample } \\
\text { No. }\end{array}$ & $\begin{array}{l}\mathrm{Fe} \\
\%\end{array}$ & $\begin{array}{l}\mathrm{Pb} \\
\%\end{array}$ & $\begin{array}{l}\mathrm{Zn} \\
\%\end{array}$ & $\begin{array}{c}\mathrm{Cu} \\
\mathrm{mg} / \mathrm{kg}\end{array}$ & $\begin{array}{c}\text { In } \\
\mathrm{mg} / \mathrm{kg}\end{array}$ & $\begin{array}{c}\mathrm{Ga} \\
\mathrm{mg} / \mathrm{kg}\end{array}$ & $\begin{array}{c}\mathrm{Ge} \\
\mathrm{mg} / \mathrm{kg}\end{array}$ & $\begin{array}{c}\mathrm{Se} \\
\mathrm{mg} / \mathrm{kg}\end{array}$ & $\begin{array}{c}\mathrm{Te} \\
\mathrm{mg} / \mathrm{kg}\end{array}$ & $\begin{array}{c}\mathrm{Y} \\
\mathrm{mg} / \mathrm{kg}\end{array}$ & $\begin{array}{c}\text { Mo } \\
\mathrm{mg} / \mathrm{kg}\end{array}$ & $\begin{array}{c}\operatorname{Re} \\
\mathrm{mg} / \mathrm{kg}\end{array}$ & $\begin{array}{c}\mathrm{W} \\
\mathrm{mg} / \mathrm{kg}\end{array}$ & $\begin{array}{c}\mathrm{Sm} \\
\mathrm{mg} / \mathrm{kg}\end{array}$ & $\begin{array}{c}\text { Eu } \\
\mathrm{mg} / \mathrm{kg}\end{array}$ & $\begin{array}{c}\mathrm{Ba} \\
\mathrm{mg} / \mathrm{kg}\end{array}$ & $\underset{\mathrm{mg} / \mathrm{kg}}{\mathrm{Ag}}$ & $\begin{array}{c}\mathrm{Au} \\
\mathrm{mg} / \mathrm{kg}\end{array}$ & $\underset{\mathrm{mg} / \mathrm{kg}}{\mathrm{U}}$ \\
\hline EJ-3 & 3.56 & 0.08 & 0.61 & 1787 & 8 & 71 & 141.8 & 8 & 38 & 213 & 350 & 1 & 837 & 37 & 6 & 3046 & 206 & 41 & 95 \\
\hline EJ-4 & 12.84 & 0.08 & 0.13 & 50 & 4 & 33 & 273.7 & 89 & 76 & 70 & 1325 & N.D & 651 & 15 & 3 & 58 & 216 & 100 & 21 \\
\hline EJ-5 & 4.79 & 0.17 & 0.30 & 92 & 2 & 13 & 123.1 & 31 & 28 & 37 & 4787 & 2 & 1006 & 12 & 1 & 524 & 325 & 132 & 39 \\
\hline EJ-7 & 2.95 & 0.29 & 0.01 & 175 & 6 & 53 & 111.3 & 6 & - & 334 & 657 & 1 & 876 & 42 & 4 & 4843 & 157 & 10 & 114 \\
\hline EJ-8 & 4.18 & 0.20 & 0.71 & 1751 & 5 & 38 & 106.9 & 75 & 16 & 9 & 262 & 2 & 1202 & 1 & N.D & 1990 & 124 & 304 & 4 \\
\hline EJ-10 & 1.85 & 0.45 & 0.39 & 2690 & 11 & 89 & 94.5 & 135 & - & 59 & 755 & 3 & 673 & 15 & 2 & 304 & 158 & 30 & 14 \\
\hline
\end{tabular}



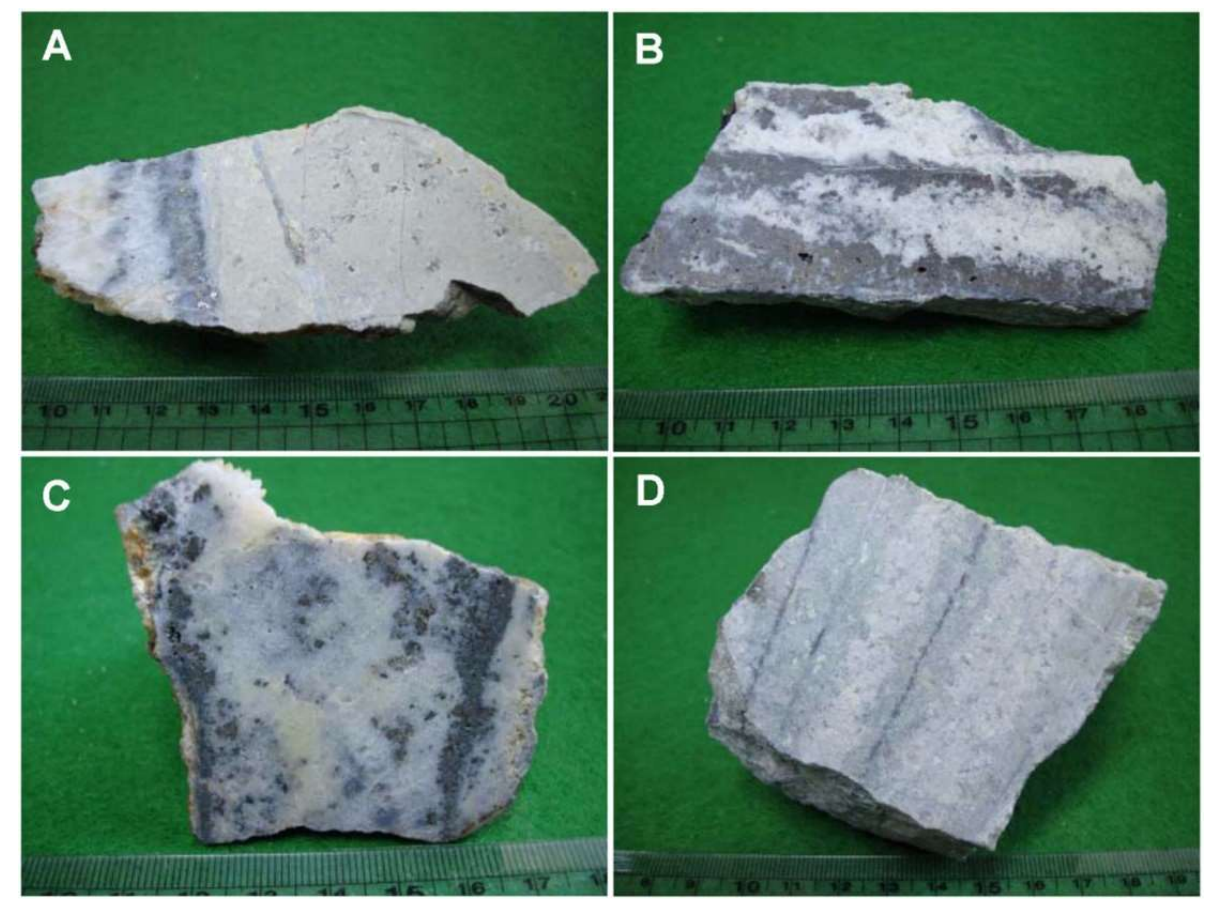

Figure 4. Photographs of high-grade ore specimens from the Eunjeok deposit. (A) Quartz vein showing comb structure as well as vug. Dark brown sphalerite, pyrite, chalcopyrite, galena, and arsenopyrite were observed. Sample No. EJ-3, Au 41.3 g/t, Ag, 206 g/t, (B) Comb textures with vuggy structures. Large amounts of fine-grained arsenopyrite were observed in quartz vein. Sample No. EJ-4, Au, $100 \mathrm{~g} / \mathrm{t}, \mathrm{Ag}, 216 \mathrm{~g} / \mathrm{t}$, (C) Within massive white quartz vein, large amounts of vugs developed. Fine-grained arsenopyrite observed with some pyrite and sphalerite. Sample No. EJ-5, Au, $131.6 \mathrm{~g} / \mathrm{t}, \mathrm{Ag}, 325 \mathrm{~g} / \mathrm{t}$, (D) Tuffs were altered, fine-grained galena and chalcopyrite concentrated along the fractures. Epidotization occur along the fractures. Sample No. EJ-10, Au, 29.8 g/t, Ag, 158g/t.

Three distinct alteration zones based on major mineral assemblages were identified in the Eunjeok deposit. These alteration zones were defined by thin sections and XRD studies. Each alteration zone is graded into the next zone without a sharp boundary. The width of vein-related alteration haloes varies in proportion to vein thickness. The presence of additional fractures in the vein walls may increase the width of these haloes. Figure 5 shows the generalized alteration zoning of the strongly altered wall rock from the Eunjeok deposit. Altered wall rocks vary in color and texture. Adjacent to a vein, the wall rock is commonly bleached to a whitish color. This gradually grades outward through yellowish-green into normal greenish propylitized rock. Closest to the vein, the wall-rock was converted to a continuous envelope of fine-grained quartz-kaolinite-rare sericite. This alteration zone is graded into a completely recrystallized assemblage of quartz-sericite-chlorite, which in turn grades outward into a rock in which primary volcanic textures can be recognized. In this transitional zone, sericite dominates and replaces feldspar in the matrix.

The vein-related alteration assemblages grade into quartz-sericite-chlorite-feldspar (adularia)-calcite assemblages of typical propylitically altered rocks. Figure 6 shows that the alteration path depends on the temperature for the Eunjeok deposit.

Sericite from a vein alteration halo in the Eunjeok deposit was measured to be a K-Ar date of $86 \pm 7.7 \mathrm{Ma}$, indicating a Late Cretaceous age for $\mathrm{Au}-\mathrm{Ag}$ mineralization (Table 2). 


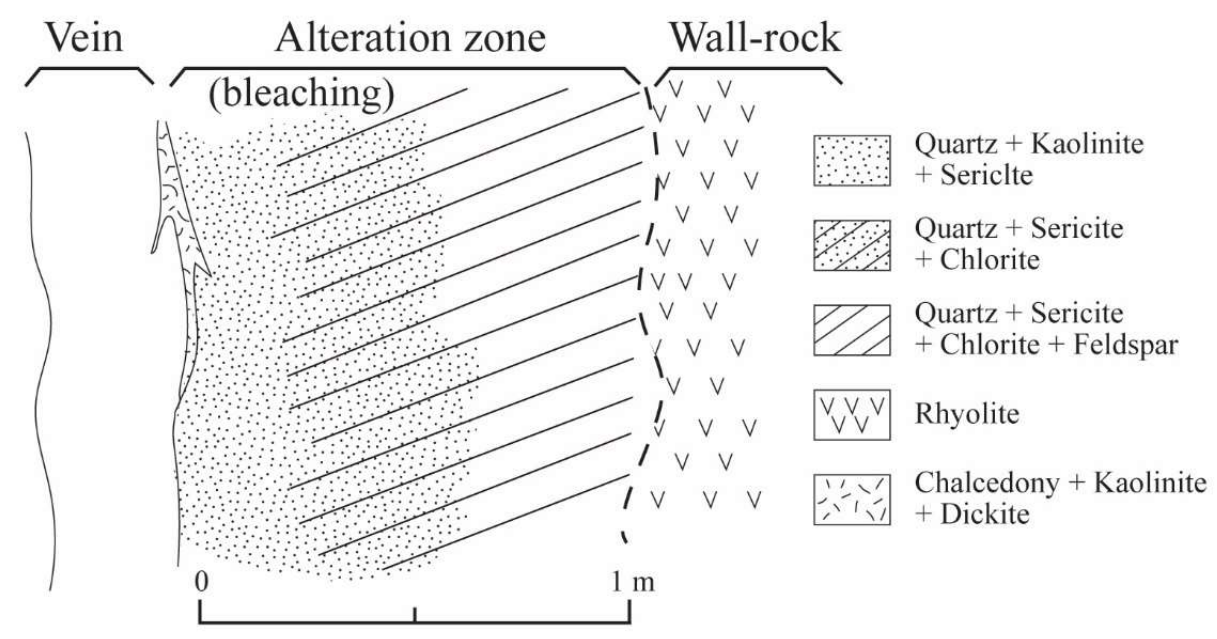

Figure 5. Sketch map of alteration zoning in the strong altered wall-rock from the Eunjeok deposit.

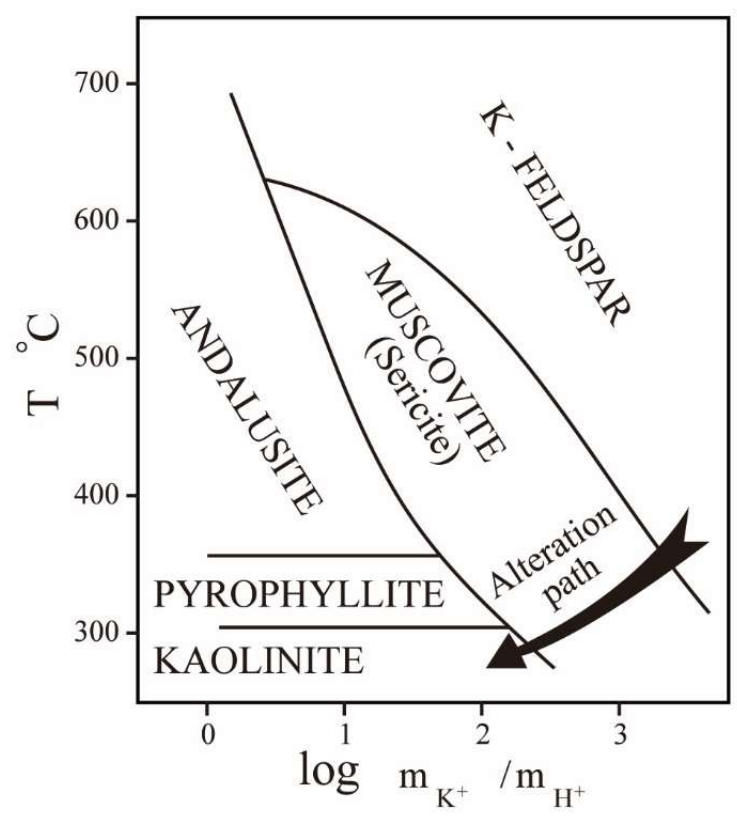

Figure 6. Alteration path depending on the temperature for the Eunjeok deposit modified from [18].

Table 2. K-Ar data of alteration sericite, Eunjeok Au-Ag deposit.

\begin{tabular}{ccccc}
\hline Description & K (\%) & ${ }^{40} \mathrm{Ar}(\mathrm{mol} / \mathrm{g})$ & ${ }^{40} \mathrm{Ar}$ Rad. (\%) & Age (Ma) \\
\hline Sericite from alteration selvage & 7.40 & $1.3236 \times 10^{-10}$ & 80.49 & $86.15 \pm 7.7$ \\
\hline
\end{tabular}

\section{Mineralization and Paragenesis}

The common characteristics of open space filling in numerous epithermal deposits, such as crustification and brecciation, and small vugs commonly occur in the Au-Agbearing quartz veins from the Eunjeok deposit. The textural relationships in the field and hand specimens indicate that the veins were created in four paragenetic stages separated by fracturing and brecciation events. During stage I and III mineralization, barren white to milky quartz with minor amounts of sulfides was deposited in the fracture system. During stage II, quartz with an economic concentration of Ag and As minerals associated with base metal sulfides was deposited. Stage IV is marked by carbonates. The main vein of the Eunjeok deposit contains mineralization in all three stages. The mineralization and paragenesis of the studied deposit are summarized in Figure 7. 


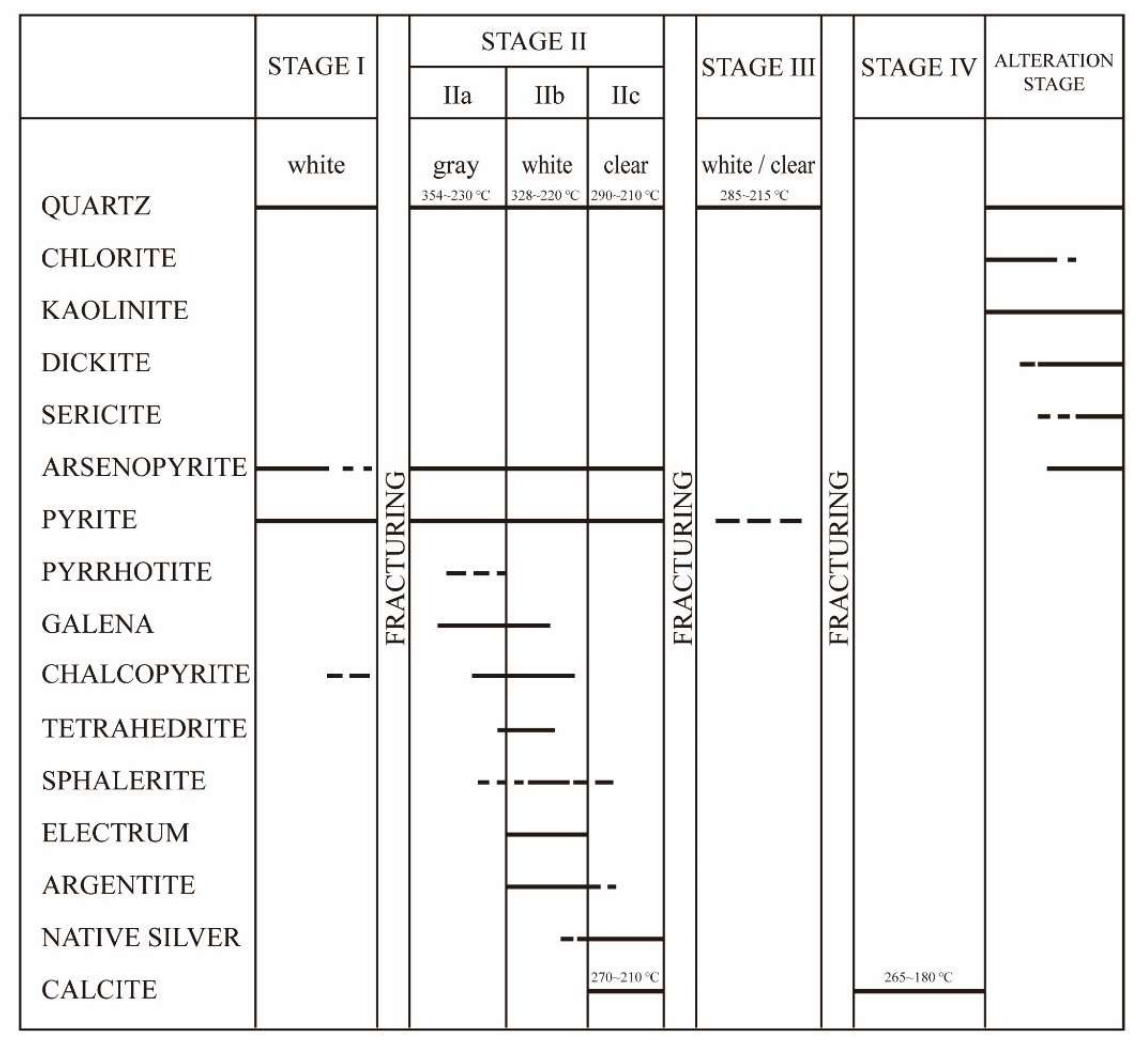

Figure 7. Vein mineralogical paragenesis of Eunjeok gold-silver deposit.

\subsection{Stage I Vein Mineralization}

This stage is composed of massive white quartz and minor amounts of arsenopyrite, pyrite, and chalcopyrite. Stage I quartz veins, usually less than $10 \mathrm{~cm}$, often contain altered wall-rock breccias. Arsenopyrite occurs often in the form of fine- to mediumgrained disseminations throughout the veins and, frequently, as aggregates of anhedral grains that are intimately intergrown with pyrite and chalcopyrite at the edges of the vein. Fine-grained euhedral pyrite rarely occurs in small vugs or as individual euhedral grains included in the vug filling quartz.

\subsection{Stage II Vein Mineralization}

Stage II veins are economically the most significant and display paragenesis sequences in which two substages are present in relation to time and space: the vein and vug stage.

Vein Stage: Mineralization in the vein stage is characterized by early (IIa) and late (IIb) mineralization based on quartz morphology and mineral assemblages. Early mineralization (IIa) is represented by mostly early gray quartz with large amounts of arsenopyrite and pyrite and minor amounts of chalcopyrite, pyrrhotite, and sphalerite. Fine-grained gray quartz at the edges of the vein grows inwardly as prismatic crystals. Early arsenopyrite is predominantly observed as euhedral to subhedral grains with a characteristic rhombic shape in host rocks and near the margin of the vein. Some arsenopyrite is in the form of polycrystalline aggregates and rarely massive bands, ranging from a few millimeters to $10 \mathrm{~mm}$ in thickness, at the edges of the veins. Representative electron microprobe analyses of arsenopyrite are presented in Table 3. The compositions (32.20 to 31.47 atomic\% As) of arsenopyrite analyzed by electron probe microanalyzer (EPMA) lie close to the line representing the stoichiometric composition and do not show compositional zoning. Pyrite occurred as dominant subhedral to euhedral grains commonly disseminated in the host rocks and does not contain inclusions of other ore minerals; however, vein pyrite often includes small irregular and rounded grains of pyrrhotite and chalcopyrite. Rare pyrrhotite blebs and chalcopyrite disease were included in sphalerite (Figure 8A). Minor amounts of chalcopyrite are interstitial to granular aggregates of pyrite and arsenopyrite. Iron-rich 
sphalerite occurs as small inclusions in arsenopyrite and pyrite. These sphalerites contain $\mathrm{FeS}$ mole\% of 17.50 to 18.20 , as shown in Table 4 . Late mineralization (IIb) of the vein stage is represented by white quartz with electrum, argentite, and base metal sulfides such as chalcopyrite, sphalerite, galena, and rare native silver. White quartz, occurring as a coarsegrained crystal, overgrows on the prismatic IIa gray quartz crystal. Pyrite and arsenopyrite (30.10 to 30.96 atomic \% As) occur as fine-grained disseminates. Irregular corroded margins are commonly observed on pyrite by galena along the irregular cracks. Some highly brecciated arsenopyrite fragments are cemented by galena and chalcopyrite associated with electrum and argentite. Chalcopyrite is associated with galena and sphalerite (Figure 8B) and occurs as interstitials to other sulfides. Sphalerite and galena occurrences were minor and not economically significant. Reddish-brown sphalerite occurs as polycrystalline aggregates associated with electrum and argentite and rare native silver in the intermediate zone of the veins. Their FeS contents are between 8.58 and 10.71 mole \%. Highly brecciated sphalerite was cemented and replaced by galena. Most sphalerite contains oriented rows of chalcopyrite blebs. Tetrahedrite is commonly associated with galena, replacing sphalerite. Tetrahedrite grains are rarely coprecipitated with argentite within the galena matrix and are interstitial to euhedral pyrite and arsenopyrite. Gold occurs as small grains of electrum (less than $1 \mathrm{~mm}$ ) containing 62.77 to $78.15 \mathrm{wt} . \% \mathrm{Ag}$ (Table 5). According to [19], goldsilver alloys with fines 200 to 800 are classified as electrum. In case of Eunjeok $\mathrm{Au}-\mathrm{Ag}$ deposit, the fineness ranges from 219 to 375 (avg. $=309, \mathrm{~N}=5)$, indicating electrum. Electrum-formed ellipsoidal grains are intimately associated with galena (Figure 8C) and occur as isolated inclusions in late pyrite and arsenopyrite. Argentite commonly occurs as replacements surrounding and replacing sphalerite and galena (Figure 8D). In addition, its small grains are included in the galena. EPMA analysis indicates that argentite contains 59.86 to 66.44 atomic \% of $\mathrm{Ag}$ [20].
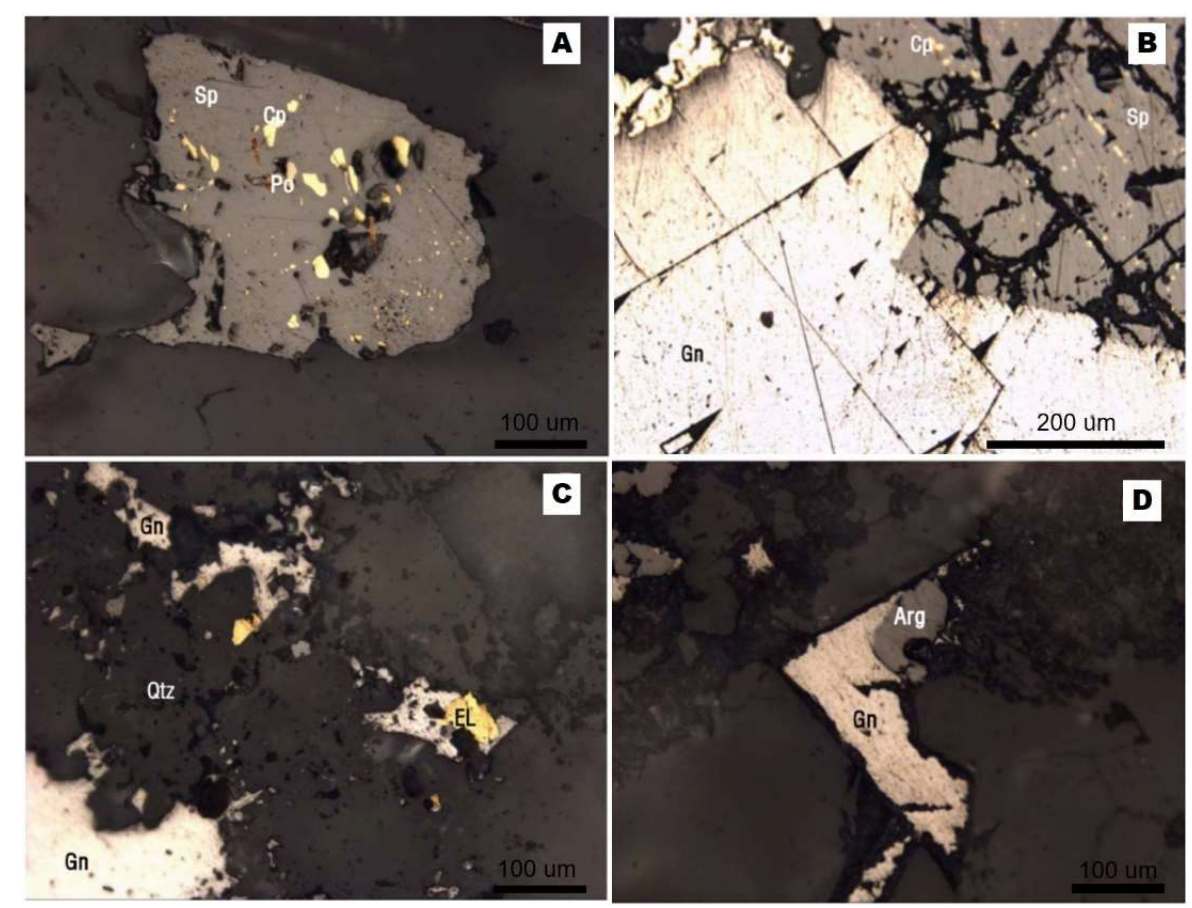

Figure 8. Reflected photomicrographs of ore specimens from the Eunjeok deposit. (A) Pyrrhotite bleb and chalcopyrite disease in sphalerite; (B) Galena with chalcopyrite disease in sphalerite; (C) electrum coexisting with galena infilling the quartz vein fracture; (D) infilling of the quartz vein by argentite and galena. Abbreviations: $\operatorname{Arg}=$ argentite, $\mathrm{Cp}=$ chalcopyrite, $\mathrm{EL}=$ elctrum, $\mathrm{Gn}=$ galena, $\mathrm{Sp}=$ sphalerite, $\mathrm{po}=$ pyrrhotite, $\mathrm{Qtz}=$ quartz . 
Table 3. EPMA data of stage II arsenopyrites from the Eunjeok Au-Ag deposit.

\begin{tabular}{cccccccc}
\hline Sample No. & Stage & $\begin{array}{c}\text { Association } \\
\text { Minerals }\end{array}$ & Fe (wt.\%) & As (wt.\%) & S (wt.\%) & Total & As (atomic \%) \\
\hline Ej-3 & IIa & py + asp & 34.65 & 43.90 & 21.52 & 99.92 & 31.21 \\
Ej-5 & IIa & py + asp & 35.08 & 44.24 & 21.08 & 101.06 & 31.47 \\
Ej-6 & IIa & py + asp & 34.89 & 43.51 & 20.53 & 98.93 & 31.47 \\
Ej-12 & IIb & py + asp + sp & 35.29 & 42.81 & 21.70 & 99.80 & 30.40 \\
Ej-13 & IIb & py + asp + el + sp + arg & 35.11 & 43.40 & 21.26 & 99.77 & 30.96 \\
Ej-16 & IIc & py + arg + cp + gn & 34.50 & 42.63 & 22.56 & 99.69 & 30.10 \\
Ej-19 & IIc & py + asp & 35.01 & 43.22 & 21.94 & 100.17 & 30.56 \\
\hline
\end{tabular}

Abbreviations: $\arg =$ argentite, asp = arsenopyrite, $\mathrm{cp}=$ chalcopyrite, $\mathrm{el}=$ elctrum, $\mathrm{gn}=$ galena, $\mathrm{py}=$ pyrite, $\mathrm{sp}=$ sphalerite.

Table 4. FeS mole\% of stage II sphalerites by EPMA analyses from the Eunjeok Au-Ag deposit.

\begin{tabular}{|c|c|c|c|}
\hline Sample No. & Stage & Association Minerals & FeS (mole \%) \\
\hline Ej-1 & IIa & $p y+a s p+p o$ & 18.20 \\
\hline $\mathrm{Ej}-2$ & IIa & py + asp & 17.50 \\
\hline Ej-3 & $\mathrm{IIb}$ & $a s p+g n$ & 10.71 \\
\hline $\mathrm{Ej}-8$ & $\mathrm{IIb}$ & asp + py & 8.95 \\
\hline Ej-9 & $\mathrm{IIb}$ & $\mathrm{py}+\arg +\mathrm{el}+\mathrm{gn}+\mathrm{cp}$ & 8.58 \\
\hline Ej-11 & $\mathrm{IIb}$ & asp + py & 8.95 \\
\hline Ej-14 & $\mathrm{IIb}$ & $\mathrm{asp}+\mathrm{gn}+\mathrm{el}+\arg$ & 10.71 \\
\hline Ej-15 & $\mathrm{IIb}$ & py + el + gn & 10.24 \\
\hline Ej-17 & $\mathrm{IIb}$ & $a s p+p y+e l+g n$ & 9.80 \\
\hline $\mathrm{Ej}-22$ & $\mathrm{IIb}$ & py $+\mathrm{el}+\mathrm{gn}$ & 10.02 \\
\hline
\end{tabular}

Table 5. EPMA data of electrum from the Eunjeok Au-Ag deposit.

\begin{tabular}{cccc}
\hline Sample No. & Au (wt. \%) & Ag (wt. \%) & $\begin{array}{c}\text { Atomic Fraction } \\
\left(\mathbf{N}_{\mathbf{A g}}\right)\end{array}$ \\
\hline Ej-9 & 37.60 & 62.77 & 0.7529 \\
Ej-13 & 27.89 & 71.40 & 0.8238 \\
Ej-14 & 33.24 & 66.71 & 0.7857 \\
Ej-15 & 33.30 & 65.70 & 0.7777 \\
Ej-17 & 21.85 & 78.15 & 0.8672 \\
\hline
\end{tabular}

Vug stage (IIc): The mineralization of the vug stage is characterized by clear quartz, native silver, pyrite, and calcite. Native silver overgrew on vug quartz as acicular or wire. This is often associated with pyrite. Some native silver is commonly interstitial to the late quartz boundaries. The economic quantities of silver in the Eunjeok deposit are concentrated in the vug stage. White calcite is the most recent gangue mineral in stage II mineralization. Massive calcite rhythmically overgrows vug quartz, and fine euhedral crystals are rarely observed in small vugs.

\subsection{Stage III Vein Mineralization}

Stage III veins contain breccias of early materials and occur along both sides of the stage II veins. This stage was composed of white quartz and minor amounts of pyrite. It contains numerous elongated cavities with clear quartz prisms, and often, chalcedonic quartz rhythmically overgrows around the orbs of earlier materials. Pyrite is disseminated through the veins as fine euhedral to subhedral grains.

\subsection{Stage IV Vein Mineralization}

This was the final stage of the hydrothermal mineralization. The latest phase of tectonic activity occurred after the mineralization of the stage II veins. Later movement in the vein is indicated by the presence of several narrow later carbonate veinlets within the massive quartz vein. This stage is composed of only white calcite. 


\section{Fluid Inclusion Study}

Fluid inclusion studies were conducted on 53 samples from the Eunjeok deposit. Doubly polished plates were prepared from vein materials, including quartz and calcite. During the measurement, temperature determinations were performed on 682 inclusions and salinity determinations on 56 inclusions. Microthermometric measurements were performed using a U.S.G.S. gas-flow heating/freezing system. Replicate measurements of homogenization temperatures indicated reproducibility within $\pm 3.0^{\circ} \mathrm{C}$ at temperatures near $350{ }^{\circ} \mathrm{C}$. Replicate measurements of the melting temperature of $\mathrm{H}_{2} \mathrm{O}$ - and $\mathrm{CO}_{2}$-rich fluid inclusions indicated a reproducibility within $\pm 0.2{ }^{\circ} \mathrm{C}$. The salinity data are based on freezing point depression in the $\mathrm{H}_{2} \mathrm{O}-\mathrm{NaCl}$ system [21]. The minerals studied in most of the plates contained numerous primary and secondary inclusions. Only liquid-rich type I inclusions are recognized based on their phase relations at room temperature, according to the terminology of [22]. Type I fluid inclusions contain liquid and vapor phases. The bubble usually makes up $20-30 \%$ of the total volume of the inclusions and is homogenized to the liquid phase during the heating test. No liquid $\mathrm{CO}_{2}$ or daughter minerals were observed in these inclusions. They are generally less than $10 \mu \mathrm{m} \mathrm{mm}$ in diameter. Gas hydrates were not observed during freezing tests.

\subsection{Inclusions in Stage II Veins}

Stage II minerals examined for the fluid inclusion study were gray and white vein quartz, clear vug quartz, and calcite. The gray and white vein quartz contains mainly secondary and primary type I inclusions. The cavity sizes of the inclusions ranged from less than $10 \mu \mathrm{m}$. Various inclusions were not suitable for the measurement of heating and freezing temperatures because they were too small in cavity size. Fluid inclusions in vug quartz and calcite occur as regular facetted cavities and often as negative inclusions. The homogenization temperatures of the primary fluid inclusions for all minerals in stage II ranged from 354 to $210^{\circ} \mathrm{C}$ (Figure 9). The homogenization temperatures of the fluid inclusions in the vein quartz ranged from 354 to $220^{\circ} \mathrm{C}$ (gray quartz, $354-230^{\circ} \mathrm{C}$; white quartz, 328-220 ${ }^{\circ} \mathrm{C}$ ). Fluid inclusions in the vug quartz and calcite were homogenized at temperatures of $290-210^{\circ} \mathrm{C}$ and $270-210^{\circ} \mathrm{C}$, respectively. The measured salinities of the primary fluid inclusions of stage II minerals were between 5.4 and $1.0 \mathrm{wt} . \%$ eq. $\mathrm{NaCl}$. The salinities of the fluid inclusions in the gray, white, and clear quartz were 5.4 to $4.5,4.6$ to 2.7, and 3.5 to 1.0 wt.\% eq. NaCl, respectively (Figure 10).

\subsection{Inclusions in Stage III Vein}

The stage III mineral examined was only white quartz. The inclusion varied in cavity sizes from 5 to $20 \mu \mathrm{m}$. The limited data obtained were gathered from the veins overgrowing and cutting stage I gray quartz. The homogenization temperatures of the primary fluid inclusions in white quartz ranged from 285 to $215^{\circ} \mathrm{C}$ (Figure 9).

\subsection{Inclusions in Stage IV Carbonate Vein}

Massive white calcite from stage IV mineralization predominantly contained secondary and rare primary inclusions. The cavity size of the primary inclusion was usually less than $20 \mu \mathrm{m}$, and the bubble occupied less than $30 \%$ of the inclusion volume. The homogenization temperature of the primary fluid inclusions in calcite ranged from 265 to $180^{\circ} \mathrm{C}$.

\subsection{Variations in Temperature and Composition of Auriferous Fluids}

During the mineralization episodes, variations in the temperatures and compositions of $\mathrm{Au}-\mathrm{Ag}$-bearing hydrothermal fluids were documented by fluid inclusions. Fluid inclusion data show that stages I and II evolved from an initial high temperature $\left(350^{\circ} \mathrm{C}\right)$ to a later lower temperature $\left(200^{\circ} \mathrm{C}\right)$. The homogenization temperature of primary inclusions in minerals from all stages decreased systematically with time and space (Figures 9 and 10). There is a distinct indication that homogenization temperatures for vug clear quartz and calcite of stage II deposition $\left(210\right.$ to $\left.290^{\circ} \mathrm{C}\right)$ were lower than the homogenization temper- 
ature for vein quartz (IIa, 204-314 ${ }^{\circ} \mathrm{C}$; $\mathrm{IIb}, 230-303{ }^{\circ} \mathrm{C}$ ) depositions. The salinity of clear vug quartz ( 1.0 to $3.5 \mathrm{wt} . \%$ eq. $\mathrm{NaCl}$ ) was lower than that $(2.5$ to $5.4 \mathrm{wt} . \%$ eq. $\mathrm{NaCl}$ ) of vein quartz. The homogenization temperature and salinity decrease indicated that the hydrothermal ore fluid was cooled and diluted by increasing the influx of meteoric water during mineralization.

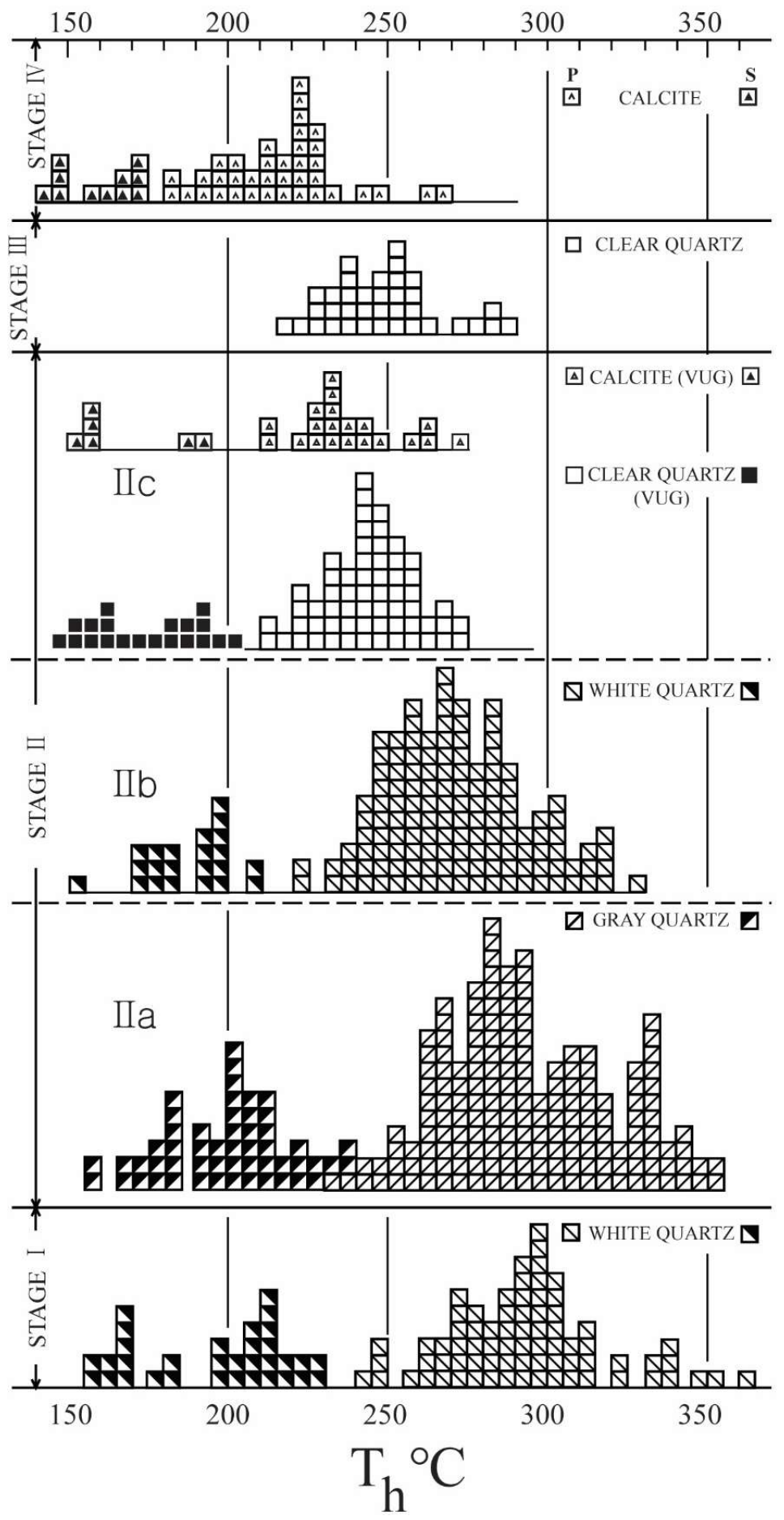

Figure 9. Homogenization temperature histograms of fluid inclusions in vein minerals from Eunjeok $\mathrm{Au}-\mathrm{Ag}$ deposit. Abbreviations: $\mathrm{P}=$ primary, $\mathrm{S}=$ Secondary. 


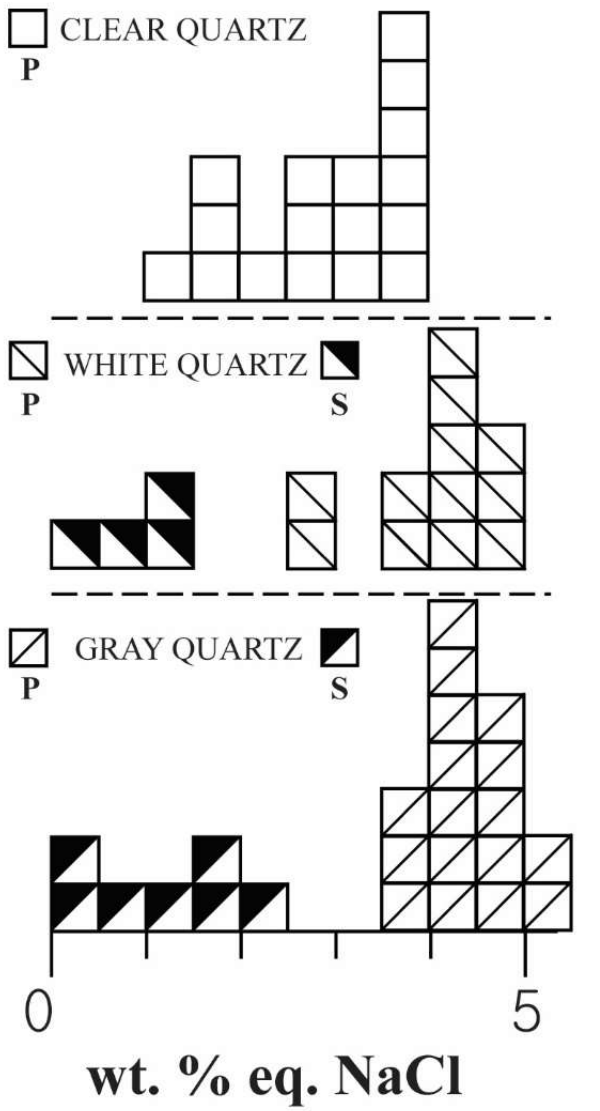

Figure 10. Salinity histograms of fluid inclusions in vein minerals of stage II from the Eunjeok $\mathrm{Au}-\mathrm{Ag}$ deposit. Abbreviations: $\mathrm{P}=$ primary, $\mathrm{S}=$ Secondary.

Low-sulfidation deposits are almost exclusively precious metal deposits with Th ranging from 120 to $320{ }^{\circ} \mathrm{C}$ and salinity from 0 to $14 \mathrm{wt} . \% \mathrm{NaCl}$, with most data in the $200-300{ }^{\circ} \mathrm{C}$ range and $<5 \mathrm{wt} . \%$ salinity [23]. Considering the characteristics of the compositional variation of epithermal fluids, the Eunjeok $\mathrm{Au}-\mathrm{Ag}$ deposit is believed to be a low-sulfidation deposit.

\section{Chemical Environments of Ore Deposits}

The typical environments of the main ore deposit types can vary in terms of $\mathrm{fS}_{2}$ and temperature. Crosscutting relationships between successive mineral assemblages facilitate evolutionary tracing of the hydrothermal system sulfidation-state [24].

To investigate the environmental conditions of the main ore mineralization in the stage II veins from the Eunjeok deposit, the compositions of arsenopyrite, electrum, and sphalerite were analyzed by EPMA. The data on these minerals are shown in Tables 3-5. The variations in sulfide assemblages in relation to time and space document decreasing sulfidation depending on decreasing temperature. Moreover, sulphidation of iron-bearing minerals in the wall rocks to form pyrite represents another effective means for reducing HS concentration [25]. The sulfidation of stage II veins is provided by fluid inclusion and stable isotope data, and the compositions of arsenopyrite and sphalerite in equilibrium with pyrite and pyrrhotite are shown in Figure 11.

Vein stage: The presence of the pyrite-arsenopyrite-pyrrhotite-sphalerite assemblage in the early mineralization (IIa) of the vein stage from the Eunjeok deposit restricts $\mathrm{fS}_{2}$ to a narrow range. The upper limit of $\mathrm{fS}_{2}$ can be set by the pyrite-arsenopyrite reaction curve [26] and isopleths of arsenopyrite and sphalerite. The lower limit of $\mathrm{fs}_{2}$ may be set by the As content of arsenopyrite and pyrite-pyrrhotite [27]. The obtained temperature of formation and $\log \mathrm{fs}_{2}$ range may be approximately $300-400{ }^{\circ} \mathrm{C}$ and -7 to $-10 \mathrm{~atm}$., respectively. 


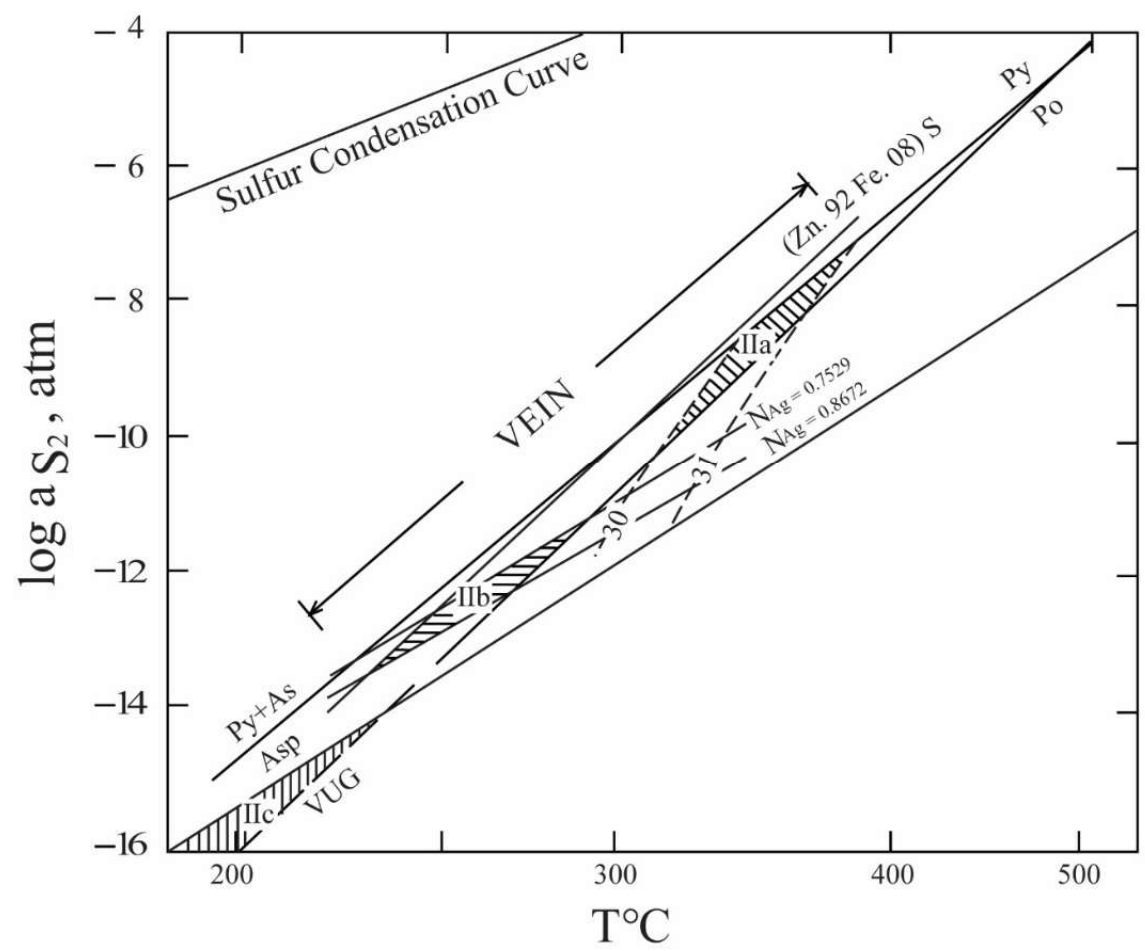

Figure 11. Sulfur fugacity versus temperature diagram showing sulfidation reactions pertinent to Eunjeok mineral assemblages. Sulfur fugacity and temperature systematically decrease from stage IIA through IIB toward IIC. These decreases are interpreted to represent repeated incursions of meteoric waters into the hydrothermal system. $\mathrm{N}_{\mathrm{Ag}}=$ atomic fraction of silver in electrum. Abbreviations: Py $=$ pyrite, As = arsenic, Asp = arsenopyrite, $\mathrm{Po}=$ pyrrhotite .

The maximum $\mathrm{fO}_{2}$ condition of pyrite-pyrrhotite stability is at the pyrite-pyrrhotitemagnetite triple point.

$6 \mathrm{FeS}+2 \mathrm{O}_{2}=\mathrm{Fe}_{3} \mathrm{O}_{4}+3 \mathrm{FeS}_{2}$

The minimum $\mathrm{fO}_{2}$ condition can be obtained as follows

$\mathrm{H}_{2}(\mathrm{~g})+1 / 2 \mathrm{O}_{2}=\mathrm{H}_{2} \mathrm{O}$, if $\mathrm{fH}_{2}=\mathrm{fH}_{2} \mathrm{O}, \log \mathrm{fO}_{2}=-2 \log \mathrm{K}$

Because the fugacity of $\mathrm{H}_{2}$ is unlikely to exceed that of water in hydrothermal ore fluids.

Assuming that the possible temperature of coexisting pyrite-pyrrhotite is near $300{ }^{\circ} \mathrm{C}$ based on fluid inclusion data, the range of $\log \mathrm{fO}_{2}$ is near $-34.4 \mathrm{~atm} . \operatorname{logm} \sum \mathrm{H}_{2} \mathrm{~S}$ can be calculated from the following equation:

$\mathrm{H}_{2} \mathrm{~S}(\mathrm{aq})+\mathrm{FeS}_{2}+1 / 2 \mathrm{O}_{2}=\mathrm{FeS}+\mathrm{H}_{2} \mathrm{O}(\mathrm{aq})$

From this equation, the calculated $\log m \sum \mathrm{S}$ is -2.2 .

The sulfidation of late mineralization (IIl) of the vein stage was estimated from the phase relations in the Fe-Zn-S system [28] and $\mathrm{Au}-\mathrm{Ag}-\mathrm{S}$ system [29]. By decreasing the temperature below $300{ }^{\circ} \mathrm{C}$, the $\mathrm{FeS}$ content of sphalerite gradually decreased from 17.1-18.2 to $8.9-10.7 \mathrm{~mole} \%$. The formation temperature of late mineralization was near $250 \pm 30^{\circ} \mathrm{C}$, which corresponds to a logfs 2 range of -12 to $-14 \mathrm{~atm}$. This formation temperature range corresponds well to fluid inclusion and stable isotope data, indicating that white quartz associated with electrum and argentite was deposited near $230-320^{\circ} \mathrm{C}$.

The association of native $\mathrm{Ag}$ and pyrite implies that their formation temperature and $\operatorname{logfS} S_{2}$ value may be less than $230{ }^{\circ} \mathrm{C}$ and $-14 \mathrm{~atm}$., respectively, based on the reaction curves of pyrite-pyrrhotite and argentite-native Ag.

\section{Stable Isotope Studies}

Recent studies have demonstrated the usefulness of stable isotopes in elucidating the origin and history of hydrothermal fluids and their constituents in vein-type gold deposits [30-36]. In this study, we measured the oxygen isotope compositions of quartz 
and calcite along with the sulfur isotope compositions of sulfide minerals. Standard techniques for extraction and analysis were used as described previously [37-41]. Isotope data are documented in standard notation relative to the Vienna SMOW standard for oxygen, Canyon Diablo Troilite standard for sulfur, and the Pee Dee Belemnite standard for carbon. The standard error of each analysis was approximately \pm 0.1 per mil for oxygen, sulfur, and carbon.

\subsection{Sulfur Isotope Study}

Analyses of sulfur isotopes were performed on 14 hand-picked sulfide minerals from the Eunjeok deposit (five pyrite, two sphalerite, and seven arsenopyrite; Table 6). Negligible change was observed in the $S$ values of the individual minerals in the ore veins. Pyrite has $S$ values between 4.91 and 6.20 per mil; sphalerite, 5.40 to 5.50 per mil; and arsenopyrite, 6.52 to 7.46 per mil. No systematic spatial or temporal variations in the $S$ values of the sulfides were discovered within the ore deposits.

Table 6. Sulfur isotope data from the Eunjeok Au-Ag deposit.

\begin{tabular}{|c|c|c|c|c|c|}
\hline Sample No. & Stage & Minerals & $\delta^{34} S(\%)$ & py-sp & $\mathrm{T}\left({ }^{\circ} \mathrm{C}\right)$ \\
\hline $\mathrm{Ej}-4$ & alteration & asp & 6.52 & & \\
\hline Ej-5 & alteration & asp & 6.70 & & \\
\hline Ej-6 & alteration & asp & 6.56 & & \\
\hline $\mathrm{Ej}-1$ & IIa & asp & 7.40 & & \\
\hline $\mathrm{Ej}-2$ & IIa & asp & 7.46 & & \\
\hline \multirow[t]{2}{*}{$\mathrm{Ej}-3$} & IIa & asp & 7.46 & & \\
\hline & IIa & py & 4.93 & & \\
\hline $\mathrm{Ej}-8$ & IIa & py & 4.91 & & \\
\hline Ej-9 & IIa & py & 5.21 & & \\
\hline \multirow[t]{3}{*}{$\mathrm{Ej}-12$} & $\mathrm{IIb}$ & py & 6.50 & 1.1 & $251 \pm 38$ \\
\hline & $\mathrm{IIb}$ & $\mathrm{sp}$ & 5.40 & & \\
\hline & $\mathrm{IIl}$ & $\mathrm{sp}$ & 5.50 & & \\
\hline Ej-14 & IIC & asp & 7.00 & & \\
\hline Ej-15 & IIC & py & 6.20 & & \\
\hline
\end{tabular}

Abbreviations: asp = arsenopyrite, $\mathrm{sp}=$ sphalerite, $\mathrm{py}=$ pyrite.

The pyrite-sphalerite pairs of stage IIb analyzed had textures suggesting coprecipitation of the phases. They had S values of approximately 1.1 per mil, yielding apparent equilibrium isotope temperatures between 251 and $38^{\circ} \mathrm{C}$ [42]. This temperature range agreed with the peak in the homogenization temperatures of primary fluid inclusions in stage IIb quartz, which corresponded to the major period of gold mineralization. Considering depositional temperatures of $350{ }^{\circ} \mathrm{C}$ for early pyrite (IIa), $300{ }^{\circ} \mathrm{C}$ for early pyrite, $250{ }^{\circ} \mathrm{C}$ for IIb pyrite and sphalerite, and $230{ }^{\circ} \mathrm{C}$ for IIc pyrite, ranges of possible $\mathrm{S}$ values of the hydrothermal fluid were calculated (using the compiled data of [42]). The ranges of calculated $\delta^{34} \mathrm{~S}$ values of sulfide minerals were early IIa pyrite, 3.7 to 4.0 per mil; IIb pyrite, 5.0 per mil; sphalerite, 5.0 to 5.1 per mil; and IIc pyrite, 4.6 per mil. The overlap in the ranges suggests that a fluid with a $\delta^{34} \mathrm{~S}_{\mathrm{H} 2 \mathrm{~S}}$ value of approximately 4 per mil was responsible for mineralization in the Eunjeok deposit. The $\delta^{34} \mathrm{~S}_{\mathrm{H} 2 \mathrm{~S}}$ values of the hydrothermal fluids in this study area recorded slight variations in the temperature range of $300-230{ }^{\circ} \mathrm{C}$. This suggests that the dominant sulfur species in the fluid was $\mathrm{H}_{2} \mathrm{~S}$. A temperature decrease of $230{ }^{\circ} \mathrm{C}$ would be ineffective for the $\delta^{34} \mathrm{~S}_{\mathrm{H} 2 \mathrm{~S}}$ value of a fluid if its sulfur species prevails as $\mathrm{H}_{2} \mathrm{~S}$. Therefore, the $\delta^{34} \mathrm{~S}_{\mathrm{H} 2 \mathrm{~S}}$ value near 4 per mil may be considered as the approximate value of the sulfur isotope composition of the entire solution $\left(\delta^{34} S_{\Sigma S}\right)$. The authors of [42] showed that a magmatic fluid phase in equilibrium with a hydrous melt of granitic composition $\left(\log \mathrm{fo}_{2}=-12,1000 \mathrm{bar}, 800{ }^{\circ} \mathrm{C}\right.$, and an initial $\mathrm{S}$ value near $0 \%$ ) will have an $\mathrm{S}$ value of approximately 4 to 5 per mil. It is therefore tempting to interpret the source of sulfur in the Eunjeok gold-silver mineralized veins as an igneous source, probably the associated Cretaceous granitic intrusion. 


\subsection{Oxygen and Carbon Isotope Studies}

The $\delta^{18} \mathrm{O}$ values of four stage III calcites from the Eunjeok deposits range from 5.53 to 5.82 per mil (Table 7). Applying the calcite-water oxygen isotope fractionation equation of [43] in conjunction with temperature estimates based on fluid inclusions and paragenetic constraints, the range of $\delta^{18} \mathrm{O}$ values of waters in equilibrium with the calcites was $2.72 \%$ to $3.01 \%$. The $\delta^{13} \mathrm{C}$ values for calcites ranged from -4.94 to -5.37 per million.

Table 7. Carbon and oxygen isotope data of calcite from the Eunjeok Au-Ag deposit.

\begin{tabular}{cccccc}
\hline Sample No. & Minerals & $\boldsymbol{\delta}^{13} \mathbf{C}(\%)$ & $\delta^{18} \mathbf{O}(\%)$ & $\delta^{18} \mathbf{O}_{\mathrm{H} 2 \mathrm{O}}(\%)$ & $\mathrm{T}\left({ }^{\circ} \mathrm{C}\right)$ \\
\hline Ej-23 & calcite & -4.93 & 5.53 & 3.01 & 220 \\
Ej-24 & calcite & -5.37 & 5.82 & 2.72 & 220 \\
\hline
\end{tabular}

\section{Discussion}

The Eunjeok Au-Ag deposit has the structural characteristics of extensional systems formed with relation to the nearly NE-trending Gwangju-Yeongdong strike-slip fault (Figures 1 and 2). Furthermore, it has been found to be associated with the Mogpo inferred cauldron [17]. Near the cauldron margin, high-angle gravity faults (e.g., Hwangsan fault) dip inwardly to the central portion of the cauldron. The occurrence of Late Cretaceous (i.e., $86 \mathrm{Ma}$ ) gold-silver mineralization in the Eunjeok deposit may indicate that the tectonic setting of the Korean Peninsula during this time affected the suitable environment for ore formation. This indicates that epithermal gold-silver mineralization in South Korea mainly occurred from ca. 100 to $70 \mathrm{Ma}$, corresponding to the Bulgugsa magmatic event [2,44,45]. Based on fluid inclusion studies, we suggest that the auriferous hydrothermal ore fluid in the Eunjeok deposit was cooled and diluted by increasing the influx of meteoric water during mineralization, implying that a very shallow environment was accompanied by epithermal precious-metal mineralization. It is also suggested that cauldron-related fractures as the predominant fluid conduit are important in forming the Cretaceous epithermal Eunjeok gold-silver deposit.

As is well known, Cretaceous epithermal Au-Ag deposits in South Korea are related tectonically to pull-apart basins and volcano-tectonic depressions $[1,2,7,8,16,46]$. Two representative epithermal gold-silver mineralized areas were recognized: the Mugeuk and Haenam-Jindo districts (Figure 1). To understand the genetic nature of Cretaceous auriferous hydrothermal systems in South Korea, comprehensive contrasts among Eunjeok, Mugeuk, and Haenam-Jindo mineralization episodes will be meaningful (Table 8).

Table 8. Comparison of general characteristic features, mineral composition, fluid inclusion, and stable isotope data for the representative Cretaceous gold-silver deposits in South Korea.

\begin{tabular}{|c|c|c|c|}
\hline Deposit & Eunjeok $[11,12]$ & Mugeuk $[4-7,10]$ & Haenam-Jindo $[3,9,47,48]$ \\
\hline Geologic setting & $\begin{array}{c}\text { Volcano-tectonic } \\
\text { setting(Mokpo cauldron) }\end{array}$ & $\begin{array}{l}\text { Pull-apart sedimentary } \\
\text { setting(Eumseong basin) }\end{array}$ & $\begin{array}{l}\text { Volcano-tectonic setting } \\
\text { (Haenam basin) }\end{array}$ \\
\hline Major fault system & Gwangju-Hwangsan fault & Gongju-Eumseong fault & $\begin{array}{l}\text { Gwangju-Yeongdong fault } \\
\text { Intermediate-to-silicic }\end{array}$ \\
\hline Host rock & $\begin{array}{l}\text { Late Cretaceous } \\
\text { volcanics, granite }\end{array}$ & $\begin{array}{l}\text { Jurassic granitoids and } \\
\text { sedimentary rocks }\end{array}$ & $\begin{array}{l}\text { extrusive rocks in the } \\
\text { Cretaceous } \\
\text { volcano-tectonic terrane }\end{array}$ \\
\hline $\begin{array}{l}\text { Age of gold-silver } \\
\text { mineralization }\end{array}$ & $86.0 \mathrm{Ma}$ & 105.7 or $98.0 \mathrm{Ma}$ & $<70.3 \mathrm{Ma}$ \\
\hline Commodities & $\mathrm{Ag} \geq \mathrm{Au}$ & $\mathrm{Ag} \geq \mathrm{Au}$ & $\mathrm{Ag} \gg \mathrm{Au}$ \\
\hline $\begin{array}{l}\text { Mineral composition } \\
\text { (range, average) }\end{array}$ & & & \\
\hline $\mathrm{Au}(\mathrm{at} . \%)$ in el & $62.77-78.15$ & $5.2-82.0$ & $8.6-57.5$ \\
\hline $\mathrm{FeS}(\mathrm{mole} \%)$ in sp & $8.58-10.71$ & $0.03-7.4$ & $0.2-6.6$ \\
\hline As (at.\%) in ap & $31.47-32.20$ & $28.5-32.7$ & Not found \\
\hline
\end{tabular}


Table 8. Cont.

\begin{tabular}{|c|c|c|c|}
\hline Deposit & Eunjeok $[11,12]$ & Mugeuk $[4-7,10]$ & Haenam-Jindo $[3,9,47,48]$ \\
\hline \multicolumn{4}{|l|}{ Fluid inclusion data } \\
\hline Fluid system & $\mathrm{H}_{2} \mathrm{O}-\mathrm{NaCl}$ & $\mathrm{H}_{2} \mathrm{O}-\mathrm{NaCl}$ & $\mathrm{H}_{2} \mathrm{O} /-\mathrm{CO}_{2}-\mathrm{NaCl}$ \\
\hline Type & $\mathrm{I} \gg \mathrm{II}$ & $\mathrm{I} \gg \mathrm{II}$ & I $>$ II $>$ III \\
\hline $\operatorname{Th}\left({ }^{\circ} \mathrm{C}\right)$ & $204-314$ & $137-341$ & $113-298$ \\
\hline $\begin{array}{c}\text { Salinity } \\
\text { (wt.\% equiv. } \mathrm{NaCl})\end{array}$ & $2.5-5.4$ & $0.8-7.9$ & $0.0-3.4$ \\
\hline \multicolumn{4}{|l|}{$\begin{array}{c}\text { Isotope data } \\
\text { (range, average) }\end{array}$} \\
\hline \multicolumn{4}{|l|}{ (range, average) } \\
\hline \multicolumn{4}{|l|}{ Oxygen $(\%$ ) } \\
\hline quartz & - & $7.7-12.7,9.4$ & $1.6-10.2$ \\
\hline calculated $\delta^{18} \mathrm{O}_{\mathrm{H} 2 \mathrm{O}}$ & - & -1.2 to $3.8,0.5$ & -10.1 to -2.1 \\
\hline carbonate & $5.53-5.82$ & 6.9 & $0.0-3.8$ \\
\hline calculated $\delta^{18} \mathrm{O}_{\mathrm{H} 2 \mathrm{O}}$ & $2.72-3.01$ & -2.6 & -9.5 to -7.8 \\
\hline \multicolumn{4}{|l|}{ Hydrogen $(\%$ ) } \\
\hline quartz & - & -73 to $-71,-72$ & -76 to -71 \\
\hline carbonate & - & -76 & -80 to -52 \\
\hline Carbon $(\%)$ (carbonate) & -4.94 to -5.37 & -4.7 & -6.9 to -5.0 \\
\hline Sulfur $(\%)$ & -4.91 to -7.46 & - & - \\
\hline calculated $\delta^{34} \mathrm{~S}_{\mathrm{H} 2 \mathrm{~S}}$ & $3.7-5.1$ & - & - \\
\hline
\end{tabular}

Mugeuk epithermal gold-silver (-antimony) deposits of the Eumseong pull-apart basin are situated in central South Korea $[4-6,10]$. They occur within Jurassic granitoids and sedimentary rocks and have the structural characteristics of extensional systems in relation to the NE-trending Gongju-Eumseong fault. In contrast, Cretaceous Haenam-Jindo epithermal gold-silver deposits are distributed in calc-alkaline volcano-tectonic depressions $[3,47,48]$. They have intermediate-to-silicic extrusive lithologies in the Cretaceous volcano-tectonic terrane and have the characteristics of extensional systems with respect to the NE-trending Gwangju-Yeongdong fault.

As shown in Table 8, variations in auriferous ore-forming fluids are projected onto the mineralogical and geochemical characteristics of the Cretaceous Korean epithermal Au-Ag deposits. The Mugeuk gold-silver deposits are estimated to be epithermal-to-mesothermal deposits [4-6,10], whereas the Haenam-Jindo gold-silver deposits are unquestionable as epithermal deposits $[3,47,48]$. In contrast, the Eunjeok deposit has some similarities with Haenam-Jindo deposits in terms of geologic setting, major fault system, host rock, and age of gold-silver mineralization, whereas they share some characteristics with Mugeuk deposits based on mineral composition and fluid inclusion characteristics. In terms of tectonic evolution, it is thought that the Haenam-Jindo and Eunjeok deposits experienced similar periods of volcano-tectonic depression, resulting in similar host rock and related fault systems $[3,9,16,49-51]$. In contrast, Mugeuk and Eunjeok deposits show similar fluid inclusion characteristics, such as the inflow of progressively less evolved meteoric waters during the deposition of gold-silver mineralization [10-12]. The above-mentioned Cretaceous gold-silver deposits have a wide range with variable average values in terms of the gold composition of the electrum, implying dramatic mineralogical and geochemical variations among these deposits [52-54]. These considerable variations may indicate that the chemical composition of the auriferous hydrothermal fluids changed rapidly in response to various physicochemical variables in the epithermal environment.

\section{Conclusions}

The Eunjeok $\mathrm{Au}-\mathrm{Ag}$ deposit is genetically related to Late Cretaceous magmatism (i.e., Bulgugsa event, ca. 110-60 Ma) which was caused by the transition in subduction direction and style of the Izanagi Plate [55]. Considering the characteristics of geologic setting, major fault system, and host rock, the Eunjeok Au-Ag deposit within the Yeongam district tends to share general geologic characteristics with those of Haenam-Jindo ep- 
ithermal mineralization episodes. However, the age of gold-silver mineralization is older than that of Haenam-Jindo epithermal mineralization episodes, implying that there are some differences in the genetic sequence of extensional features (i.e., fluid conduit) related to transcurrent Gwangju-Yeongdong strike-slip movement. The auriferous fluids with the $\mathrm{H}_{2} \mathrm{O}-\mathrm{NaCl}$ system in the Eunjeok deposit have homogenization temperatures and salinities of $204-314^{\circ} \mathrm{C}$ and less than $10 \mathrm{wt} . \%$ equiv. $\mathrm{NaCl}$ and experienced mixing (dilution and cooling) events during mineralization. In terms of the depositional mechanism, the characteristics of auriferous fluids in the Eunjeok deposit share fluid characteristics with those of Mugeuk deposits rather than Haenam-Jindo deposits.

Author Contributions: Conceptualization, C.-H.H. and S.-Y.K.; methodology, S.-Y.K. and C.-H.H.; writing-original draft preparation, S.-Y.K., C.-H.H., and I.-H.O.; writing-review and editing, I.-H.O. and C.-H.H. All authors have read and agreed to the published version of the manuscript.

Funding: This research was supported by the Basic Research Project of the Korea Institute of Geoscience and Mineral Resources, Daejeon, South Korea, funded by the Ministry of Science and ICT of Korea (GP2020-007).

Data Availability Statement: The data is shown in the table of the article.

Acknowledgments: We appreciate the anonymous reviewers and the associate editor for constructive review comments to improve the quality of the manuscript.

Conflicts of Interest: The authors declare no conflict of interest.

\section{References}

1. Choi, S.G.; Ryu, I.C.; Wee, S.M.; Kim, C.S.; Pak, S.J. Overview of Epithermal Gold-Silver Mineralization, Korea; Tectonics and Genetic Implication. In The Origin of Granites and Related Rocks. The 5th Hutton Symposium, Toyohashi, Japan; The Geological Survey of Japan: Tokyo, Japan, 2003; Volume 29, p. 23.

2. Choi, S.G.; Ryu, I.C.; Pak, S.J.; Wee, S.M.; Kim, C.S.; Park, M.E. Cretaceous Epithermal Gold-Silver Mineralization and Geodynamic Environment, Korea. Ore Geol. Rev. 2005, 26, 115-135. [CrossRef]

3. Lee, G.; Koh, S.M.; Pirajno, F. Evolution of Hydrothermal Fluids of HS and LS Type Epithermal Au-Ag Deposits in the Seongsan Hydrothermal System of the Cretaceous Haenam Volcanic Field, South Korea. Ore Geol. Rev. 2014, 61, 33-51. [CrossRef]

4. Shin, Y.W.; Suh, K.S. Exploration and Development of the Muguk Au Mine. Korea Inst. Min. Geol. J. 1987, 20, 261-271. (In Korean)

5. Park, H.I.; Kang, S.J. Gold and Silver Mineralization of Samhyungje Vein, the Mugeug Mine. Korea Inst. Min. Geol. J. 1988, 21, 257-268. (In Korean)

6. Kim, K.H.; Kim, O.J.; Chang, H.W. Stable Isotope and Fluid Inclusion Studies of the Mugug Au-Ag Mineral Deposits. Korean Inst. Min. Geol. J. 1990, 23, 1-9. (In Korean)

7. Choi, S.G.; Lee, D.E.; Pak, S.J.; Choi, S.H.; Kang, H.S. Genetic Model of Mineral Exploration for the Korean Au-Ag Deposits: Mugeug Mineralized Area. Econ. Environ. Geol. 2001, 34, 423-435, (In Korean with English abstract).

8. Choi, S.G. The Genetic Implications of Mesozoic Gold-Silver Mineralization, Korea. In Proceedings of the Mesozoic Sedimentation, Igneous Activity and Mineralization in South Korea, Korea Institute of Geology, Mining and Materials; Jin, M.J., Lee, S.R., Chon, H.I., Park, K.H., Koh, S.M., Cho, D.L., Eds.; Special Publications: Daejeon, Korea, 2002; Volume 1, pp. $216-226$.

9. Kim, C.S.; Choi, S.G.; Choi, S.H.; Lee, I.W. Hydrothermal Alteration and Its Genetic Implication in the Gasado Volcanic-Hosted Epithermal Gold-Silver Deposit: Use in Exploration. J. Miner. Soc. Korea 2002, 15, 205-220, (In Korean with English abstract).

10. So, C.S.; Yun, S.T.; Youm, S.J.; Shelton, K.L.; Heo, C.H.; Choi, S.G. Episodic meteoric water interaction in a granite-hosted hydrothermal gold-silver system: Geochemistry of fluids at the Mugeuk mine, South Korea. Geochem. J. 2005, 39, 227-240. [CrossRef]

11. Heo, C.H.; Park, S.W.; Lee, J.H. Revaluation of Ore Deposits within the Yeongam District, Cheollanamdo-Province: The Eunjeok and Sangeun Mines. Econ. Environ. Geol. 2010, 43, 73-84.

12. Lee, C.S.; Kim, J.; Kim, H.N. Mineralization of the Gold-Silver Ore Deposits in Naju-Youngam Area. J. Earth Sci. Educ. Soc. 1996, 17, 166-173.

13. Na, K.C.; Lee, D.J. Preliminary Age Study of the Gyeonggi Metamorphic Belt by the Rb-Sr Whole Rock Method. J. Geol. Soc. Korea 1973, 9, 168-174.

14. Cheong, C.S.; Kwon, S.T.; Park, K.H. Pb and Nd Isotopic Constraints on Paleoproterozoic Crustal Evolution of the Northeastern Yeongnam Massif, South Korea. Precambrian Res. 2000, 102, 207-220. [CrossRef]

15. Cluzel, D.; Jolivet, L.; Cadet, J.P. Early Middle Paleozoic Intraplate Orogeny in the Ogcheon Belt (South Korea): A New Insight on the Paleozoic Buildup of East Asia. Tectonics 1991, 10, 1130-1151. [CrossRef]

16. Chough, S.K.; Kwon, S.T.; Ree, J.H.; Choi, D.K. Tectonic and Sedimentary Evolution of the Korean Peninsula: A Review and New View. Ear. Sci. Rev. 2000, 52, 175-235. [CrossRef] 
17. Cha, M.S.; Yun, S.H. Cretaceous Volcanic Cauldrons and Ring Complexes. J. Geol. Soc. Korea 1988, $24,67-86$.

18. Larsson, D. Transition of granite to quartz-kyanite rock at Hålsjöberg, southern Sweden: Consequence of acid leaching and later metamorphism. GFF 2001, 123, 237-246. [CrossRef]

19. Morrison, G.W.; Rose, W.J.; Jaireth, S. Geological and geochemical controls on the silver content (fineness) of gold in gold-silver deposits. Ore Geol. Rev. 1991, 6, 333-364. [CrossRef]

20. Yun, J.H. Geochemistry of Hydrothermal Gold-Silver Deposit in Korea. Ph.D. Thesis, Seoul National University: Seoul, korea, 1989; p. 191.

21. Potter, R.W., III. Pressure Corrections for Fluid-Inclusion Homogenization Temperature Based on the Volumetric Properties of the System NaCl- $\mathrm{H}_{2}$ O. USA Geol. Surv. J. Res. 1977, 5, 603-607.

22. Nash, J.T. Fluid Inclusion Petrology, Data from Porphyry Copper Deposits and Applications to Exploration. In United States Geological Survey, Professional; U.S. Government Printing Office: WA, USA, 1976; p. 907-D.

23. Bodnar, R.J.; Lecumberri-Sanchez, P.; Moncada, D.; Steele-MacInnis, M. Fluid inclusions in Hydrothermal Ore Deposits. In Treatise on Geochemistry, 2nd ed.; Holland, H.D., Turekian, K.K., Eds.; Elsevier: Oxford, UK, 2014; pp. 119-142.

24. Fontbote, L.; Kouzmanov, K.; Chiaradia, M.; Pokrovski, G.S. Sufide mineraqls in hydrothermal deposits. Elements 2017, 13, 97-103. [CrossRef]

25. Willams-Jones, A.E.; Bowell, R.J.; Migdisov, A.A. Gold in Solution. Elements 2009, 5, 281-287. [CrossRef]

26. Kretschmar, U.; Scott, S.D. Phase Relations Involving Arsenopyrite in the System Fe-As-S and Their Application. Can. Mineral. 1976, 14, 364-386.

27. Barton, P.B., Jr.; Toulmin, P. III. Phase Relations Involving Sphalerite in the Fe-Zn-S System. Econ. Geol. 1966, 61, 815-849. [CrossRef]

28. Scott, S.D.; Barnes, H.L. Sphalerite Geothermometry and Geobarometry. Econ. Geol. 1971, 66, 653-669. [CrossRef]

29. Barton, P.B., Jr.; Toulmin, P., III. The Electrum Tarnish Method for Determination of the Fugacity of Sulfur in Laboratory Sulfide Systems. Geochim. Comsmochim. Acta 1964, 28, 619-640. [CrossRef]

30. Taylor, H.P., Jr. $\mathrm{O}^{18} / \mathrm{O}^{16}$ Evidence for Meteoric-Hydrothermal Alteration and Ore Deposition in the Tonopah, Comstock Lode, and Goldfield Mining Districts, Nevada. Econ. Geol. 1973, 68, 747-764. [CrossRef]

31. O'Neil, J.R.; Silberman, M.L. Stable Isotope Relations in Epithermal Au-Ag Deposits. Econ. Geol. 1974, 69, 902-909. [CrossRef]

32. Rye, D.M.; Rye, R.O. Homestake Gold Mine, South Dakota: I. Stable Isotope Studies. Econ. Geol. 1974, 69, 293-317. [CrossRef]

33. Rye, R.O.; Doe, B.R.; Wells, J.D. Stable Isotope and Lead Isotope Study of the Cortez, Nevada Gold Deposit and Surrounding Area. USA Geol. Surv. J. Res. 1974, 2, 13-23.

34. Casadevall, T.; Ohmoto, H. Sunnyside Mine, Eureka Minining District, San Juan County, Colorado; Geochemistry of Gold and Base Metal Ore Deposition in a Volcanic Environment. Econ. Geol. 1977, 72, 1285-1320. [CrossRef]

35. Kerrich, R.; Allison, I. Vein Geometry and Hydrostatics during Yellowknife Mineralisation. Can. J. Earth Sci. 1978, 15, 1653-1660. [CrossRef]

36. Kesler, S.E.; Russell, N.; Seaward, M.; Rivera, J.; McCurdy, K.; Cumming, G.L.; Sutter, J.F. Geology and Geochemistry of Sulfide Mineralization Underlying the Pueblo Viejo Gold-Silver Oxide Deposit, Dominican Republic. Econ. Geol. 1981, 76, 1096-1117. [CrossRef]

37. McCrea, J.M. On the Isotopic Carbonates and a Paleotemperature Scale. J. Chem. Phys. 1950, 18, 849-857. [CrossRef]

38. Grinenko, V.A. Preparation of Sulfur Dioxide for Isotopic Analysis. Zh. Neorg. Khim. 1962, 7, $2478-2483$.

39. Hall, W.E.; Friedman, I. Composition of Fluid Inclusions, Cave-in-Rock Fluorite District, Illinois and Upper Mississippi Valley Zinc-Lead District. Econ. Geol. 1963, 58, 886-911. [CrossRef]

40. Roedder, E.; Ingram, B.; Hall, W.E. Studies of Fluid Inclusions. [Part] 3. Extraction and Quantitative Analysis of Inclusions in the Milligram Range. Econ. Geol. 1963, 58, 353-374. [CrossRef]

41. Rye, R.O. The Carbon, Hydrogen, and Oxygen Isotopic Composition of the Hydrothermal Fluids Responsible for the Lead-Zinc Deposits at Providencia, Zacatecas, Mexico. Econ. Geol. 1966, 61, 1399-1427. [CrossRef]

42. Ohomoto, H.; Rye, R.O. Isotopes of Sulfur and Carbon. Geochem. Hydro. In Ore Deposits, 2nd ed.; Barnes, H.L., Ed.; Wiley Interscience: New York, NY, USA, 1979; pp. 509-567.

43. O'Neil, J.R.; Clayton, R.N.; Mayeda, T.K. Oxygen Isotope Fractionation in Divalent Metal Carbonates. J. Chem. Phys. 1969, 51, 5547-5558. [CrossRef]

44. Shimazaki, H.; Lee, M.S.; Tsusue, A.; Kaneda, H. Three Epochs of Gold Mineralization in South Korea. J. Min. Geol. 1986, 36, 265-272.

45. Cho, D.R.; Kwon, S.T. Hornblende Geobarometry of the Mesozoic Granitoids in South Korea and the Evolution of the Crustal Thickness. J. Geol. Soc. Korea 1994, 30, 41-61, (in Korean with English abstract).

46. Choi, S.G.; Choi, S.H. Contrasting Style of Gold and Silver Mineralization in the Central and Southeastern Korea. Econ. Environ. Geol. 1995, 28, 587-597.

47. Kim, C.S. Genesis of the Cretaceous Low-Sulfidation Epithermal Au-Ag Deposits in the Haenam District, Republic of Korea. Ph.D. Thesis, Korea University, Seoul, Korea, 2011.

48. Yang, S.J.; Duuring, P.; Kim, Y.S. Structural Genesis of the Eunsan and Moisan Low-Sulphidation Epithermal Au-Ag Deposits, Seongsan District, Sothwest Korea. Miner. Depos. 2013, 48, 467-483. [CrossRef] 
49. Kim, I.J.; Nagao, K. K-Ar Ages of the Hydrothermal Clay Deposits and the Surrounding Igneous Rocks in Southwest Korea. J. Petrogr. Soc. Kor. 1992, 1, 58-70.

50. Chun, S.S.; Chough, S.K. The Cretaceous Uhangri Formation, SW Korea: Lacustrine Margin Facies. Sedimentology 1995, 42, 293-322. [CrossRef]

51. Koh, S.; Takagi, T.; Kim, M.; Naito, K.; Hong, S.; Sudo, S. Geological and Geochemical Characteristics of the Hydrothermal Clay Alteration in South Korea. Resour. Geol. 2000, 50, 229-242. [CrossRef]

52. Shikazono, N.; Shimizu, M. Compositional Variations in Au-Ag Series Mineral from Some Gold Deposits in the Korean Peninsula. J. Min. Geol. 1986, 36, 545-554.

53. Sugaki, A.; Kim, O.J.; Kim, W.J. Gold and Silver Ores from Geumwang Mine in South Korea and Their Mineralization. J. Min. Geol. 1986, 36, 555-572.

54. Choi, S.G.; Wee, S.M. The Genetic Characteristics of Gold and/or Silver Vein Deposits Related to Chemical Composition of Electrum in Central Korea. J. Geol. Soc. Korea 1992, 28, 196-217, (in Korean with English abstract).

55. Maruyama, S.; Isozaki, Y.; Kimura, G.; Terabayashi, M. Paleogeographic Maps of the Japanese Islands: Plate Tectonic Synthesis from 750Ma to the Present. Isl. Arc. 1997, 6, 121-142. [CrossRef] 